\title{
ARTICLES
}

\section{ENDING RACIAL PROFILING OF AFRICAN-AMERICANS IN THE SELECTIVE ENFORCEMENT OF LAWS: IN SEARCH OF VIABLE REMEDIES}

Floyd Weatherspoon ${ }^{*}$

Table of Contents

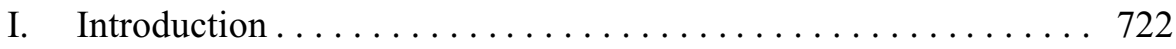

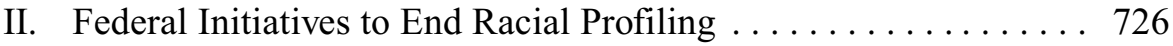

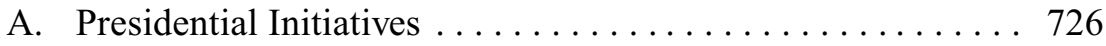

B. Congressional Legislation: Racial Profiling Act of 2001 . . 729

C. Racial Profiling Education and Awareness Act of 2002 . . . . 730

D. U.S. Justice Department, Civil Rights Division . . . . . . . 732

1. The Violent Crime Control and Law Enforcement Act of

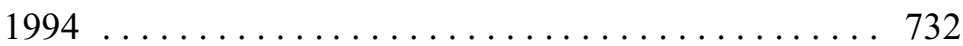

2. Omnibus Crime Control and Safe Streets Act of 1968 . . 735

3. Title VI of the Civil Rights Act ............ 736

III. State and Local Initiatives $\ldots \ldots \ldots \ldots \ldots \ldots \ldots \ldots \ldots \ldots$

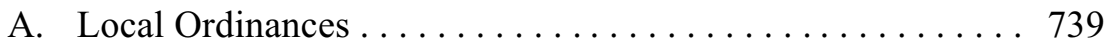

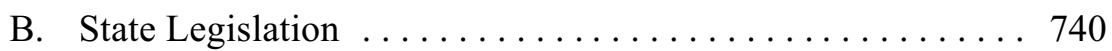

C. Collection of Data ................... 743

* C 2003, Floyd D. Weatherspoon, Professor of Law, Capital University Law School(Columbus, Ohio). B.S., North Carolina A\&T State University, 1974; J.D., Howard University Law School, 1977. I am especially grateful to my research assistants Victoria Beale, Jenny Maag-Swinerton, Mara Smith, Stacie Isaacs, and Jennifer Jung. Ron Wittel, a third year law student, also provided valuable research data for this article. I am also thankful to Dean Steven Bahls, Capital University Law School for providing a generous summer stipend to research and write this article. 
D. Training and Development $\ldots \ldots \ldots \ldots \ldots \ldots \ldots \ldots \ldots$

IV. Individual Citizen Response . . . . . . . . . . . . . . . . . . 749

A. Citizen Complaints . . . . . . . . . . . . . . . . . . 749

B. Civil Suits Under $\S 1983 \ldots \ldots \ldots \ldots \ldots \ldots \ldots \ldots \ldots$

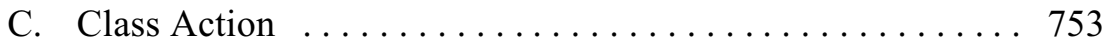

V. Community and Organization Initiatives $\ldots \ldots \ldots \ldots \ldots \ldots \ldots$

A. Community Initiative Response $\ldots \ldots \ldots \ldots \ldots \ldots \ldots 756$

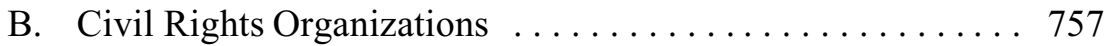

C. State and Local Bar Association Initiatives . . . . . . . . . 759

D. Local Enforcement Organizations . . . . . . . . . . . . 759

VI. Conclusion ......................... 761

\section{INTRODUCTION}

In theory, the American justice system is designed to ensure that each American's basic constitutional rights are preserved and protected. Most Americans, including African-Americans, believe that the justice system protects the constitutional rights of all Americans. However, the extent of this protection is viewed differently by whites and African-Americans. ${ }^{1}$ Indeed, African-Americans feel that their constitutional rights have been marginalized by the very systems in place to protect their rights. ${ }^{2}$

The Constitution guarantees equal protection under the law, ${ }^{3}$ the right to travel, ${ }^{4}$ the right to vote,${ }^{5}$ and the right to privacy. ${ }^{6}$ But for African-

1. A number of surveys have determined that minorities feel that whites are treated more favorably by the justice system. For example, in a 1999 survey conducted by the American Bar Association of 1000 individuals, $47 \%$ disagreed with the statement "[i]n most cases, the courts treat all ethnic and racial groups the same." ABA, Perceptions of the U.S. Justice System, available at www.abanet.org/media/perception 65. html (last visited Mar. 10, 2004). Similarly, a USA Today poll conducted in 1992 determined that " $81 \%$ of blacks and $36 \%$ of whites believe the justice system is biased against blacks," David Treadwell \& Edith Stanley, King Case Aftermath: A City in Crisis, L.A. Times, May 2, 1992, at A7; see also Justice System Seen as Racist by U.S. Public, WASH. Post, July 30, 1989, at A20 (survey of 1000 Americans overwhelmingly felt that the "criminal justice system is plagued by racism and that whites and blacks do not get equal sentences for the same crime").

2. In a 1999 survey by the National Center for State Courts, approximately 1900 individuals were surveyed and the results indicated that "[t]wo-thirds of African-Americans feel that 'people like them' are treated somewhat or far worse than other people." NCSC, How the Public Views the Courts, available at http://www.ncsonline.org/WC/Publications (last visited Mar. 10,2004). Almost 70\% of African-American respondents said that African-Americans, as a group, receive "Somewhat Worse" or "Far Worse" treatment from the courts; a substantial number (over 40\%) of Whites/Non-Hispanics and Hispanic respondents agreed. $I d$.

3. U.S. CONST. amend. XIV, $\S 1$.

4. The right to travel has several potential sources in the Constitution. See, e.g., Zobel v. Williams, 
Americans, these rights are merely a mirage of what white Americans receive and take for granted. Their constitutional rights are especially abridged in the enforcement of laws related to travel. Too often, race is the determinative factor used by law enforcement officers to justify a stop and search of African-Americans. Even though the Constitution prohibits such conduct by law enforcement agencies, these practices have become the norm, not the exception.

The American justice system has permitted, and in some cases sanctioned, the use of the immutable characteristic of race as the motivating factor in the enforcement of public laws. ${ }^{7}$ Such actions or inactions on the part of individuals entrusted with the enforcement of public laws have served as a detriment to the idea that all Americans have inalienable rights. In other words, in their zeal to enforce public laws, governmental officials have selected African-Americans and other minorities ${ }^{8}$ solely on the basis of their

457 U.S. 55, $78-79$ (1982) (O’Connor, J., concurring) (stating the right to travel has historically been associated with the Privileges and Immunities Clause of Article IV of the United States Constitution); Edwards v. California, 314 U.S. 160 (1941) (finding transportation of people falls under rubric of the Commerce Clause of the United States Constitution); id. at 178 (Douglas, J., concurring) (stating right to interstate travel is grounded in the Privileges and Immunities Clause of the Fourteenth Amendment, prohibiting state interference); see also Zobel, 457 U.S. at 67 (Brennan, J., concurring) (stating that even without a citable source within the Constitution, the right to travel freely between the states is contained in the essence of the Constitution).

5. U.S. Const. amend. XV, § I. See The Sentencing Project, Losing the Vote: The Impact of Felony Disenfranchisment Laws in the United States, available at http://www.hrw.org/reports98/vote (last visited Mar. 10, 2004) (finding that millions of Americans have permanently lost the right to vote because of a felony conviction, especially African-Americans).

6. Griswold v. Connecticut, 381 U.S. 479, 486 (1965).

7. See Erika L. Johnson, "A Menace to Society:” The Use of Criminal Profiles and Its Effects on Black Males, 38 How. L.J. 629 (1995); United States v. Coleman, 450 F. Supp. 433 (E.D. Mich. 1978); Amy D. Ronner, Fleeing While Black: The Fourth Amendment Apartheid, 32 Colum. Hum. RTs. Rev. 383 (2001) (arguing the U.S. Supreme Court's decisions in Terry and Wardlow limit Fourth Amendment protections for minorities); Mary Maxwell Thomas, The African-American Male: Common Gap Coverts Justice into "Just Us" System, 13 Harv. BlackLetTer L.J. 1, 28 (1997); Floyd D. Weatherspoon, The Devastating Impact of the Justice System on the Status of African-American Males: An Overview Perspective, 23 CAP. U. L. REv. 23 (1994) (discussing how African-American males are disproportionately arrested and incarcerated).

8. This article focuses on African-Americans and racial profiling; however, there is evidence that racial profiling is also directed at other racial groups. The remedies and initiatives discussed in this article should also lessen the impact of racial profiling on other minorities as well. See Kevin R. Johnson, The Case for African Americans and Latina/o Cooperation in Challenging Racial Profiling in Law Enforcement, 55 Fla. L. Rev. 341 (2003); Susan Sachs, Files Suggest Profiling of Latinos Led to Immigration Raids, N.Y. Times, May 1, 2001, at B1. There is also evidence that after the terrorist attack on the World Trade Center on September 11, 2001, individuals who appeared to be of Middle Eastern ancestry were stopped by law enforcement officials based on ethnic profiling. See Kevin R. Johnson, The Case Against Race Profiling in Immigration Enforcement, 78 WASH. U. L.Q. 675 (2000); David A. Harris, 
race to stop, arrest, charge, prosecute, and incarcerate. ${ }^{9}$ This practice has been described as "driving while black" and racial profiling. ${ }^{10}$ Racial profiling involves the pre-disposition that minorities are engaged in criminal activities, which results in minorities being stopped and searched without probable cause. ${ }^{11}$

New Approaches to Ensuring the Legitimacy of Police Conduct: Racial Profiling Redux, 22 ST. LouIS U. Pub. L. Rev. 73 (2003); Deborah A. Ramirez et al., Defining Racial Profiling in a Post-September 11th World, 40 AM. CRIM. L. Rev. 1195 (2003).

9. See Patrick A. Langan et al., U.S. Department of Justice, Contacts Between Police and the Public (Feb. 2001). This report to Congress, as required by the Violent Crime Control and Law Enforcement Act of 1994 revealed, in part, the following data regarding African-American drivers:

- Blacks were more likely than whites to be stopped at least once, and blacks were more likely than whites to be stopped more than once. $I d$. at 1 .

- During the traffic stop, police were more likely to carry out some type of search on a black than a white. Id. at 2 .

- Blacks and Hispanics stopped by police were more likely than whites to be arrested. Id. at 16 .

- Black and Hispanic motorists were more likely than white motorists to be subjected to a search of the driver. $I d$. at 18.

Even though the study did not conclude that the above disparities were a result of racial profiling, the numbers illustrate that African-Americans were disproportionately stopped and searched.

With regard to incarceration, the incarceration rate of African-Americans is staggering. The Bureau of Justice statistics report that "approximately $46 \%$ of all prison inmates are black." Department of Justice, Census of State and Federal Correctional Facilities, 2000, available at http://www.ojp.usdoj.gov/bjs/ prisons.htm (last visited Mar. 10, 2004). In the federal prisons "[b]lack inmates comprise the largest category $(40 \%)$." Id.

10. Kenneth Meeks, Driving While Black, What to Do If You Are a Victim of Racial Profiling (2000); David A. Harris, "Driving While Black" and All Other Traffic Offenses: The Supreme Court and Pretexual Traffic Stops, 87 J. Crim. L. \& CRiminology 544, 559-71 (1997); David A. Harris, The Stories, the Statistics, and the Law: Why "Driving While Black" Matters, 84 Minn. L. Rev. 265 (1999).

11. Professor Deborah Ramirez of Northeastern University Law School defines racial profiling as "[a]ny police-initiated action that relies on race, ethnicity or national origin of an individual rather than the behavior of an individual or information that leads the police to a particular individual who has been identified as being, or having been, engaged in a criminal activity." Deborah Ramirez et al., U.S. Department of Justice, A Resource Guide on Racial Profiling Data Collection Systems, Promising Practices and Lessons Learned NCJ 184768 (Nov. 2000), available at http://www.ncjrs.org/pdffiles1/bja/ 184768.pdf (last visited Mar. 10, 2004).

The U.S. Department of Justice describes racial profiling in this manner:

"Racial profiling" at its core concerns the invidious use of race or ethnicity as a criterion in conducting stops, searches, and other law enforcement investigative procedures. It is premised on the erroneous assumption that any particular individual of one race or ethnicity is more likely to engage in misconduct than any particular individual or another race or ethnicity.

U.S. Department of Justice, Guidance Regarding the Use of Race By Federal Law Enforcement Agencies, available at http://www.usdoj.gov/ctr/split/documents/guidance_on_race.htm (last visited Mar. 10, 2004) [hereinafter Guidance Policy]. 
There is substantial evidence that racial profiling exists. ${ }^{12}$ Moreover, there is substantial jurisprudence written on racial profiling. ${ }^{13}$ What is lacking is jurisprudence on how Congress, state and federal law enforcement agencies, the courts, and the minority community can eliminate and remedy racial profiling by law enforcement officials. Therefore, this article focuses on how to eliminate and remedy such conduct.

Unfortunately, racial profiling of African-Americans appears to be ingrained in the minds of many law enforcement officers and has become a part of their standard operating procedures. A frontal attack must occur at all levels of government, the judiciary, ${ }^{14}$ by private citizens, and various community and civil rights organizations.

This article identifies various initiatives taken by all levels of the government, civil rights and community organizations, law enforcement organizations, and individual citizens to address the issue of racial profiling. The article also reviews the judiciary's response to this practice. In addition, this article presents a number of possibilities and considerations to address the issue, as well as an evaluation of the effectiveness of recently implemented programs. There is no one paradigm that will completely eradicate the practice of racial profiling. ${ }^{15}$ A holistic approach to remedying racial profiling has to be developed to address such infectious conduct by law enforcement officials.

12. See Commonwealth v. Gonsalves, 711 N.E.2d 108 (Mass. 1999). Judge Ireland in a concurring opinion describes how racial profiling is a common occurrence around the country. Id. at 116 (Ireland, J., concurring). Judge Ireland cites examples of studies which indicate racial profiling in Florida, Maryland, Massachusetts, and New Jersey. Id.

13. Jerome H. Skolnick \& Abigail Caplovitz, Guns, Drugs, and Profiling: Ways to Target Guns and Minimize Racial Profiling, 43 ARIZ. L. Rev. 413 (2001); Gregory M. Lipper, Racial Profiling, 38 Harv. J. on Legis. 551 (2001); Peter A. Lyle, Racial Profiling and the Fourth Amendment: Applying the Minority Victim Perspective to Ensure Equal Protection Under the Law, 21 B.C. THIRD WoRLD L.J. 243 (2001); Angela J. Davis, Race, Cops, and Traffic Stops, 51 U. Miami L. Rev. 425 (1997).

14. See, e.g., State v. Soto, 734 A.2d 350 (N.J. Super. Ct. Law Div. 1996). In Martinez v. Village of Mount Prospect, the judge, in an unprecedented action, recommended that the Justice Department conduct an investigation to determine how widespread racial profiling had become. Martinez v. Vill. of Mount Prospect, 92 F. Supp. 2d 780, 785-86 (N.D. Ill. 2000). Judge Castillo stated the following in his letter to the Justice Department: "I understand that it is somewhat unusual for a judge to request an investigation, yet my oath as a judge requires me to bring this potential civil rights violation to your attention. Only your investigation can bring this matter to an appropriate resolution." Id. at 786.

15. The ACLU has proposed the following remedies to end racial profiling: "end the use of pretext stops," "pass the Traffic Stops Statistics Study Act," "pass legislation on traffic stops in every state," "the Justice Department must take steps to ensure that racial profiling is not used in federally funded drug interdiction programs," and "the 50 largest US cities should voluntarily collect traffic stop data." David A. Harris, Driving While Black: Racial Profiling on Our Nation's Highways, available at http://archive. aclu.org/profiling/report (last visited Mar. 10, 2004). 
Part II of the article describes initiatives by the Executive Branch, Congress, and the U.S. Justice Department to address the issue of racial profiling and the effectiveness of certain programs. Part III describes state and local initiatives. Part IV outlines various legal actions that individual citizens may take when confronted by law enforcement officials who engage in racial profiling. Part V outlines various initiatives adopted by communities and organizations. Clearly, these remedies are not an exhaustive list of possible corrective actions, but only the beginning of a dialogue on how to end and prevent racial profiling by law enforcement organizations.

\section{Federal Initiatives to End Racial Profiling}

\section{A. Presidential Initiatives}

To have a meaningful plan at the federal level to address the issue of racial profiling, the directive must come from the highest position in the executive office - the President. In 1999, President Clinton called racial profiling "morally indefensible" and issued a directive to federal law enforcement agencies to collect and report data on the race, ethnicity, and gender of individuals stopped, questioned, and searched. ${ }^{16}$ Similarly, President Bush raised the issue of racial profiling in his speech to Congress on February 27, 2001. ${ }^{17}$ Further, President Bush directed the U.S. Attorney General "to develop specific recommendations on how to end racial profiling." $" 18$

16. Steven A. Holmes, Clinton Orders Investigation on Possible Racial Profiling, N.Y. Times, June 10, 1999, at A22. The federal law agencies required to collect and compile data included the Department of Justice, the FBI, the Drug Enforcement Administration, the National Park Service, the Customs Service, and the Immigration and Naturalization Service. Id. The Clinton-Gore Administration: Combating Racial Profiling, available at http://clinton3.nara.gov/WH/Work/06099.html (last visited Mar. 10, 2004).

17. President Bush stated:

It's wrong, and we will end it in America. In so doing, we will not hinder the work of our Nation's brave police officers. They protect us everyday - often at great risk. But by stopping the abuses of a few, we will add to the public confidence that our police offic ers earn and deserve. 147 Cong. Rec. S1609 (2001) (statement of President Bush).

18. The President stated in a memorandum to Attorney General Ashcroft:

I hereby direct you to review the use by Federal law enforcement authorities of race as a factor in conducting stops, searches and other investigative procedures. In particular, I ask that you work with the Congress to develop methods or mechanisms to collect any relevant data from federal law enforcement agencies and work in cooperation with State and local law enforcement in order to assess the extent and nature of any such practices. I further direct that you report back to me with your findings and recommendations for the improvement of the just and equal administration of our 
In a news conference on March 1, 2001, Attorney General Ashcroft announced two initiatives to fulfill the President's directive. ${ }^{19}$ First, the Attorney General announced that he would work with members of Congress for passage of legislation to address the President's directive. ${ }^{20}$ Second, the Attorney General stated that he would issue a directive requiring his office to explore the extent of racial profiling in federal law enforcement agencies and provide guidance to address such conduct. ${ }^{21}$ Unfortunately, the Attorney General and Congress have failed to pass any federal legislation prohibiting racial profiling. ${ }^{22}$

In response to the second directive, the Justice Department conducted a study on the extent of racial profiling by law enforcement agencies. Recommendations were presented to President Bush on eliminating racial profiling by federal law enforcement officials. ${ }^{23}$ President Bush accepted the recommendations and directed that the policy guidance be distributed to law enforcement agencies. On June 17, 2003, the Department of Justice issued a policy guide entitled: Guidance Regarding the Use of Race By Federal Law Enforcement Agencies [hereinafter "Guidance Policy"] to prohibit racial

Nation's laws.

George Bush, President's Memorandum on Racial Profiling, 37 Pub. Papers 9 (Feb. 27, 2001).

Even though President Bush expressed concern regarding racial profiling, a subsequent survey of African-American voters indicated little faith that the President or the government would take meaningful steps to end racial profiling. Specifically, the study stated "[t]here is no confidence at all among AfricanAmerican voters that the government or President Bush can and will put a stop to racial profiling." BAMPAC, National Poll of African American Registered Voters, available at http://www.bampac.org/ opinion polls2002.asp?index $=4$ (last visited Mar. 10, 2004). More than $40 \%$ of African-American voters say the Government can not put an end to racial profiling, while another $37 \%$ say the government can, but is not willing to do so (only 13\% say they can and will). Id . at index=24 (last visited Mar. 10, 2004). Similarly, $51 \%$ say President Bush cannot put an end to racial profiling, $23 \%$ say the government can, but is not willing to do so, and just $2 \%$ say Bush can and will put an end to the practice. Id.

19. Attorney General John Ashcroft, Attorney General News Conference (Mar. 1, 2001), available at http://www.usdoj.gov/ag/speeches/2001/030101 racialprofconf.htm (last visited Mar. 10, 2004).

20. Attorney General Ashcroft stated that he had sent a letter to Congress indicating that he would "work with them in the next six months to produce a legislative product" similar to Senator Feingold and Representative Conyer's proposals. Id.

21. Id.

22. See Derrick DePledge, Promise to End Racial Profiling on Back Burner After Sept. 11, Gannett News SerV., Apr. 19, 2002 (indicating that Attorney General Ashcroft and President Bush have not pushed for racial profiling legislation since the September 11, 2001 attack on the World Trade Center); Derrick Z. Jackson, Warning Sign for Racial Profiling Bill, Boston Globe, Jan. 10, 2003, at A15 (indicating that the Attorney General states he supports legislation on racial profiling but no bill has been reintroduced).

23. U.S. Department of Justice, Justice Department Issues Policy Guidance to Ban Racial Profiling [hereinafter Justice Department Issues Policy], available at http://www.usdoj.gov/opa/pr/2003/June/03 crt_355.htm (last visited Mar. 10, 2004). 
profiling by federal law enforcement officials. ${ }^{24}$ The policy was distributed to major law enforcement agencies. ${ }^{25}$

The Guidance Policy prohibits racial profiling in traffic stops and during investigations of criminal activities where no trustworthy evidence related to race has been presented. ${ }^{26}$ The Guidance Policy states in part:

"Racial profiling" at its core concerns the invidious use of race or ethnicity as a criterion in conducting stops, searches and other law enforcement investigative procedures. It is premised on the erroneous assumption that any particular individual of one race or ethnicity is more likely to engage in misconduct than any particular individual or another race or ethnicity. ${ }^{27}$

The Guidance Policy acknowledges that acts of racial profiling violate the constitutional rights of individuals who are selectively stopped on the basis of their race or ethnicity. Moreover, the Guidance Policy provides guidance on when law enforcement activities, such as stops and investigations, are permissible acts of racial profiling. ${ }^{28}$ The Guidance Policy permits the use of race by law enforcement when it relates to national security. ${ }^{29}$ Without further clarifications and guidelines, this broad exception may result in a continuation of racial and ethnic profiling. ${ }^{30}$

The Guidance Policy is an excellent tool for law enforcement officials to follow in performing their day-to-day traffic duties. However, the Department of Justice's Guidance Policy fails to provide mandatory guidelines which set forth uniform standards for federal law enforcement officials to follow. ${ }^{31}$ More definitive guidelines and standards would have a greater impact on eliminating racial profiling by federal law enforcement officials, ${ }^{32}$ as well as establishing a model for state and local enforcement agencies.

\section{Id.}

25. Justice Department Issues Policy, supra note 23.

26. Guidance Policy, supra note 11; U.S. Department of Justice, Fact Sheet: Racial Profiling, availableat http://www.usdoj.gov/opa/pr/2003/June/racial_profiling_fact_sheet.pdf(last visited Mar. 10, 2004).

27. Guidance Policy, supra note 11.

28. $I d$.

29. $I d$.

30. Jessamyn Blau, New Rules Ban Most Racial Profiling; Under Federal Policy, Race Can Be Used as a Factor in Cases of National Security, St. Louis Post-Dispatch, June 18, 2003, at Al.

31. See NOBLE, A Noble Perspective: Racial Profiling-A Symptom of Bias-Based Policing, at 23 (May 3, 2001) (recommending that the Justice Department form a "National Task Force on Racial Profiling" to establish standards and model policies on racial outlines).

32. V. Dion Haynes, Fight Racial Profiling at Local Level, Lawmaker Says; U.S. Guidelines Get Mixed Review, CHI. TRIB., June 29, 2003, at 8. 


\section{B. Congressional Legislation: Racial Profiling Act of 2001}

Congress has attempted to pass federal legislation to address the issue of racial profiling; however, these attempts have been futile. Representative John Conyers, Jr. first introduced the Traffic Stops Statistics Act in 1997. ${ }^{33}$ The purpose of the Act was to end the use of racial profiling based on stereotypical biases, particularly directed at African-American and Hispanic motorists. $^{34}$ The Act passed the House of Representatives but the Senate Judiciary Committee failed to vote on it. ${ }^{35}$ Representative Conyers again proposed similar legislation in $1999 .{ }^{36}$ In 2001, Representative Conyers, for the third time, proposed federal legislation to end racial profiling ${ }^{37}$ [hereinafter "The End Racial Profiling Act of 2001"]. The Senate proposed similar legislation; ${ }^{38}$ however, the sponsors failed to garner sufficient support for passage. Representative Conyers testified that since he first proposed this legislation in 1997, "the pervasive nature of racial profiling has gone from anecdote and theory to well documented fact." ${ }^{\text {39 }}$

The End Racial Profiling Act of 2001 would have banned racial profiling and required federal, state, and local enforcement agencies to develop and implement programs to eliminate the use of racial profiling in the enforcement of local and state laws. ${ }^{40}$ As an incentive to comply with the Act, federal funds would have been barred from state and local enforcement agencies for non-compliance. ${ }^{41}$

33. Traffic Stops Statistics Act of 1997, H.R. 118, 105 th Cong. (1st Sess. 1997).

34. Id.

35. 105 Bill Tracking H.R. 118 (1997).

36. Traffic Stops Statistics Act of 1999, H.R. 1443, 106th Cong. (1999) (the bill was voted out of Committee, but the Rules Committee never scheduled it for a floor vote).

37. The End Racial Profiling Act of 2001, H.R. 2074, 107th Cong. (2001) (for a brief history of Conyers efforts to pass federal legislation see History of Racial Profiling Traffic Study Statics Act, available at $\mathrm{http}: / / \mathrm{www} . h o u s e . g o v /$ conyers/news_racial_profiling.htm (last visited Mar. 10, 2004).

38. Senator Jon Corzine, a sponsor of the Act stated, "racial profiling has bred humiliation, anger, resentment and cynicism throughout this country. It has weakened respect for the law-by everyone, not just those offended." Senator Jon Corzine, Remarks Before the Senate (June 6, 2001), in 26 Seton Hall LEGIS. J. 55, 61 (2001)

39. 147 Cong. Rec. 1037 (daily ed. June 6, 2001) (statement of Rep. Conyers).

40. See supra note 30 .

41. This economic incentive is similar to Connecticut's racial profiling statute, which permits the State Attorney General to recommend to the State Office of Policy and Management to withhold state funds from a municipal department or the state police if they failed to comply with the statute. ConN. GEN. STAT. $\S 54-1 \mathrm{~m}$ (2001). See also Dwight F. Blint, Racial Profiling Law to Take Effect; Beginning Saturday, Police Must Record Reasons for Traffic Stops, Hartford Courant, Dec. 31, 1999, at A3. 
All attempts by Representative Conyers and other sponsors of federal legislation to ban racial profiling have failed. If the issue of racial profiling continues to be prevalent in our country, Congress will inevitably promulgate some modified version of Representative Conyers' proposal to collect data on traffic stops. It appears that the events of September 11th have derailed Congress's motivation to pass federal legislation banning racial profiling. Congress has a responsibility to protect the rights of all citizens, even in the midst of acts of terrorism. Without federal legislation banning such conduct, African-American citizens are without federal protection from racial profiling. It is imperative that Congress make the passage of racial profiling legislation a priority. ${ }^{42}$ Whether it is an act of Congress, a state statute, or a local ordinance, such laws must include certain provisions to ensure that the data collected is correct, validated, and credible. ${ }^{43}$

\section{Racial Profiling Education and Awareness Act of 2002}

In addition to collecting statistical data on police traffic stops, legislators have proposed educational and awareness programs on preventing racial profiling by law enforcement officers. The Racial Profiling Education and Awareness Act of 2002 would have authorized the U.S. Attorney General to carry out a racial profiling education and awareness program within the Department of Justice and to assist state and local law enforcement agencies in implementing such programs. ${ }^{44}$ The proposed Act would have acknowledged that racial and ethnic profiling exists and has not been an effective tool to uncover criminal activity, in part because those who have been profiled were law-abiding citizens. ${ }^{45}$ By acknowledging that racial profiling exists, state and local enforcement agencies can focus on how to address the issue, rather than taking a defensive position that their organization does not engage in racial profiling.

The Act was designed to foster a relationship with local communities and law enforcement agencies. It encouraged education programs to bridge the

42. Civil Rights as a Priority for the 108th Congress, 149 Cong. ReC. S103 (daily ed. Jan. 9, 2003) (statement of Sen. Feingold).

43. In Soto, the court accepted the statistical analysis of the traffic stop data to establish a prima facie case of selective enforcement. See State v. Soto, 734 A.2d 350 (N.J. Super. Ct. Law Div. 1996). See also Castaneda v. Partida, 430 U.S. 482 (1977); McCleskey v. Kemp, 481 U.S. 279 (1987).

44. S. 2114, 107th Cong. (2002).

45. The Bill states in part: "Whereas a large majority of individuals subjected to stops and other enforcement activities based on race, ethnicity, or national origin are found to be law-abiding and therefore racial profiling is not an effective means to uncover criminal activity." Id. 
gap with trust and respect. ${ }^{46}$ This in turn would have allowed an open dialogue on issues of policing and racial profiling. ${ }^{47}$ The Act also provided funding for implementing internal training programs designed to combat racial profiling. ${ }^{48}$

Promulgation of this legislation would have complemented the End Racial Profiling Act of 2001 by providing training to state and local law enforcement officers on how to correct and prevent the profiling of AfricanAmericans. ${ }^{49}$ The legislation would have provided funds to further enhance community programs designed to address the issue of racial profiling, especially in those areas where traffic stop statistics indicate that particular racial or ethnic groups are disproportionately stopped by law enforcement officers. ${ }^{50}$ The passage of the Racial Profiling Education Awareness Act of 2002, without the End Racial Profiling Act of 2001, would have been ineffective in addressing racial profiling. Educating law enforcement officers about racial profiling is a positive means of heightening their awareness of the issue; however, federal legislation, such as the Racial Profiling Act of 2001, would make racial profiling illegal with serious consequences. It would have been the impetus for law enforcement officials to cease such conduct. ${ }^{51}$ Unfortunately, Congress has failed to pass either Act. ${ }^{52}$

46. Id. Senator Voinovich, a sponsor of the bill states:

Rooted in the belief that education and dialogue are the most effective tools for bridging racial divides, my bill establishes a program within the Department of Justice to educate city leaders, police chiefs, and law enforcement personnel on the problems of racial profiling and the value of community outreach, as well as to recognize and disseminate information on "best practice" procedures for addressing police-community racial issues.

148 Cong. ReC. S2584 (daily ed. Apr. 11, 2002) (statement of Sen. Voinovich).

47. 148 CONG. REC. S2584.

48. $I d$.

49. The Bill states, in part:

The purposes of this new educational program are to (1) encourage state and local law enforcement agencies to cease existing practices that may promote racial profiling; (2) encourage involvement with the community to address the problem of racial profiling, (3) assist state and local law enforcement agencies in developing and maintaining adequate policies and procedures to prevent racial profiling, and (4) assist state and local law enforcement agencies in developing and implementing internal training programs to combat racial profiling and to foster enhanced community relations.

S.2114, 107th Cong. (2002).

50. $I d$.

51. See Leadership Conference on Civil Rights Calls on Senate to Enact Meaningful Racial Profiling Statute, AsCribe Newswire, Apr. 12, 2002 (stating that the LCCR believed that the 2002 Act is weak and calls on Congress to pass the 2001 Act).

52. The bill was referred to the Senate Committee on the Judiciary on April 11, 2002, where no further action has taken. 2002 Bill Tracking Report, S.2114. 


\section{U.S. Justice Department, Civil Rights Division}

The U.S. Justice Department is in a unique position to address the issue of racial profiling by public entities. ${ }^{53}$ A number of federal laws give the Justice Department authority to proceed with litigation to combat racial profiling. For example, the Violent Crime Control and Law Enforcement Act of 1994 provides a mechanism for the Justice Department to bring pattern or practice cases against law enforcement organizations who engage in racial profiling. ${ }^{54}$ In addition, the Justice Department may pursue an investigation of racial profiling under Title VI of the Civil Rights Act of $1964^{55}$ and the Omnibus Crime Control and Safe Streets Act of 1968. ${ }^{56}$

\section{The Violent Crime Control and Law Enforcement Act of 1994}

The Violent Crime Control and Law Enforcement Act of 1994 [hereinafter the "Law Enforcement Act"] gives the U.S. Justice Department authority to seek declaratory and equitable relief to remedy a pattern or practice of conduct by law enforcement officers that deprives individuals of their rights under the Constitution. ${ }^{57}$ Pursuant to the Law Enforcement Act, the Justice Department may initiate an investigation of management practices within a police department when complaints have been filed alleging a violation of a citizen's constitutional rights. ${ }^{58}$ If the Justice Department is unable to reach an agreement with the municipality, the Justice Department may proceed with an action in federal court against the police department. ${ }^{59}$

53. Steven H. Rosebaum, Statement Before the National Association of Police Organizations' National Law Enforcement Rights Center: Legal Rights and Legislative Seminar (Apr. 26, 1999) (available at http://www.usdoj.gov/crt/split/documents/policespeech.htm (last visited Mar. 10, 2004)).

54. 42 U.S.C. $§ 14141(2000)$.

55. See U.S. Department of Justice, Addressing Police Misconduct, available at http://www.usdoj. gov/crt/split/documents/polmis.htm (last visited Mar. 10, 2004).

56. 42 U.S.C. $\S 3789$ d.

57. Id. § $14141(\mathrm{~b})$.

58. For a discussion of the Justice Department's use of 42 U.S.C. $\S 14141$ to pursue pattern and practice cases involving law enforcement, see Marshall Miller, Police Brutality, 17 Yale L. \& PoL'y Rev. 149 (1998).

59. In 2001, the Justice Department conducted an extensive investigation of the Cincinnati Police Department's management practices and allegations of the use of excessive force by police officers. See Memorandum of Agreement Between U.S. Department of Justice and the City of Cincinnati, Ohio and the Cincinnati Police Department, available at http://www.usdoj/crt/split/Cincmoafinal.htm (last visited Mar. 10, 2004). The Justice Department reached a settlement with the City of Cincinnati and the Cincinnati Police Department on April 12, 2002. Id. The agreement called for changes in the use of force by officers, 
The Justice Department has filed five lawsuits under this Act. In 1994, the Justice Department filed a pattern or practice suit against the City of Steubenville, Ohio Police Department. ${ }^{60}$ On September 3, 1997, the City of Steubenville and the Justice Department entered into a consent decree. ${ }^{61}$ Among the ninety-nine stipulations, the city agreed that it would maintain race and gender data on all persons involved in a stop, search, or seizure. ${ }^{62}$ The second case pursued by the Justice Department was filed in 1997 against the City of Pittsburgh, Pennsylvania. ${ }^{63}$ In the third case, the City of Columbus, Ohio was sued in 1999 for police misconduct including racial profiling. ${ }^{64}$ After a number of reforms by the Columbus Police Department, the Justice Department asked the court to dismiss the action. ${ }^{65}$ The most notable case filed by the Justice Department was in 1999 involving the New Jersey State Police. ${ }^{66}$ The Justice Department alleged that the State of New Jersey and its Police Department engaged in "a pattern or practice of conduct by troopers of the New Jersey State Police that deprives persons of rights . . . under the Constitution. ${ }^{97}$ In 1999, the parties reached an agreement which resulted in

the use of video cameras, trainings, and the citizen complaint system. Id.

60. United States v. City of Steubenville Complaint, available at http://www.usdoj.gov/ $\mathrm{crt} / \mathrm{split} /$ documents/steubencomp.htm (last visited Mar. 10, 2004). The complaint stated in part that the Steubenville Police Department "engaged in a pattern or practice of subjecting individuals to excessive force; false arrests, charges, and reports; improper stops, searches, and seizures." Id.

61. See United States v. City of Steubenville, Consent Decree, available at http://www.usdoj.gov/ $\mathrm{crt} / \mathrm{split} /$ documents/steubensa.htm (last visited Mar. 10, 2004).

62. See id., item 24 .

63. See United States v. City of Pittsburgh, Consent Decree, available at http://www.usdoj.gov/crt/ split/documents/pittssa.htm (last visited Mar. 10, 2004). In 2002, the court terminated portions of the Consent Decree because the city was in substantial compliance. See United States v. City of Pittsburgh, Stipulated Order, available at http://www.usdoj.gov/crt/split/documents/pitts_stipulated_order.htm (last visited Mar. 10, 2004).

64. Kevin Johnson \& Gary Fields, U.S. Sues Ohio Capital, Alleging Police Abuses, USA Today, Oct. 22, 1999, at 4A.

65. Robert Ruth, Mark Ferenchik \& Kevin Mayhood, Civil-Rights Suit Dropped, Columbus Dispatch, Sept. 5, 2002, at A1. The City of Columbus, Division of Police agreed to implement the following changes to address the issue of racial profiling:

- Issue a directive explicitly prohibiting racial profiling by officers;

- Amend City Code to specifically include racial profiling as a criminal offense;

- $\quad$ Provide specialized training for all division personnel to address racial profiling;

- Collect data on all self-initiated stops; and

- Initiate efforts to install video and audio video recorders in cruisers.

See Resolution Pattern or Practice Litigation: Columbus Police, available at http://www.usdoj.gov/crt/split/ documents/columbus_cole_boyd_letters.htm (last visited Mar. 10, 2004).

66. See Joint Application for Entry of Consent Decree, United States v. New Jersey, available at http://www.usdoj.gov/crt/split/documents/jerseysa.htm (last visited Mar. 10, 2004).

67. $I d$. 
a consent decree requiring the State of New Jersey and its police departments to implement a number of policies to combat racial profiling. ${ }^{68}$ The fifth case was brought against the City of Los Angeles in 2000. The lawsuit alleged that the City's Police Department engaged in a pattern of civil-rights abuses, including racial profiling. ${ }^{69}$ The Justice Department reached an agreement with the City of Los Angeles in 2001. ${ }^{70}$

The Justice Department's use of the Law Enforcement Act has been a viable tool to address racial profiling by major law enforcement organizations around the country. The five suits brought by the Justice Department under the Law Enforcement Act resulted in police departments implementing comprehensive plans and programs to address patterns and practices of police abuse, including racial profiling. The Justice Department has used this federal statute effectively, but sparingly, to address an issue that appears to be widespread throughout many other law enforcement organizations around the country. Additional resources, such as budgets and staff, should be made available to the Justice Department's Special Litigation Section to expand their efforts for further enforcement of this statute.

68. In the agreement, the City agreed, in part:

The proposed Decree addresses the following matters: policy requirements and limitations on the use of race in law enforcement activities and the procedures used for conducting motor vehicle searches; documentation of traffic stops including post-stop procedures and enforcement actions; supervisory measures to promote civil rights integrity; procedures for receiving, investigating, and resolving misconduct allegations; training; respon sibilities of the Office of the New Jersey Attorney General concerning the New Jersey State Police; public reporting by the State Police about its law enforcement activities; and the establishment of an independent monitor to review and analyze implementation of the Decree by the State. Id.

69. United States v. City of Los Angeles, Consent Decree, available at http://www.usdoj. gov/crt/split/documents/laconsentpart2.htm (last visited Mar. 10, 2004).

70. In the agreement, the City agreed, in part to "[p]rohibit officers from relying on race, national origin, or ethnicity when making traffic and pedestrian stops ... [and] collect data on the race, national origin, or ethnicity of persons who are subject of traffic and pedestrian stops . . ." Justice Department Reaches Agreement with City of Los Angeles, available at http://www.usdoj.gov/opa/pr/2000/November/ $643 \mathrm{cr} . h \mathrm{tm}$ (last visited Mar. 10, 2004). For the full text of the Consent Decree, see supra note 69. The court-appointed monitor of the consent decree has reported that the City of Los Angeles has not implemented major parts of the agreement, especially the tracking of traffic stops. See Tina Daunt, LAPD Not Making Reforms, Monitor Says; Report: Overseer Contends Some Officers are Undermining the Federal Consent Decree, L.A. Times, May 15, 2002, at B3. 


\section{Omnibus Crime Control and Safe Streets Act of 1968}

The Omnibus Crime Control and Safe Streets Act of $1968^{71}$ [hereinafter the "Crime Control Act"] was promulgated to "aid State and local governments in strengthening and improving their systems of criminal justice by providing financial and technical assistance ...."72 The Crime Control Act prohibits state and local governments, who receive federal funds, from discriminating in programs or activities funded in whole or part by the federal government. ${ }^{73}$ The Civil Rights Division of the U.S. Justice Department is responsible for enforcing this statute. ${ }^{74}$ In addition to granting the Justice Department authority to bring a civil action, the Crime Control $\mathrm{Act}^{75}$ also allows individuals to pursue a private right of action. ${ }^{76}$

The Law Enforcement Assistance Administration (LEAA) was created to administer the funding and awarding of grants to state and local governments under the Crime Control Act. ${ }^{77}$ The LEAA also has authority to process complaints that allege discrimination on the part of recipients of funds awarded by LEAA. ${ }^{78}$ For those states and municipalities that permit law enforcement officials to engage in racial profiling, federal funds should be denied..$^{79}$

71. 42 U.S.C. $\S 3789 \mathrm{~d}(2000)$.

72. Pub. L. No. 96-157, § 2, 93 Stat. 1206 (1979).

73. The Act states in part:

No person in any State shall on the ground of race, color, religion, national origin, or sex be excluded from participation in, be denied the benefits of, or be subjected to discrimination under or denied employment in connection with any programs or activity funded in whole or in part with funds made available under this chapter. 42 U.S.C. $\$ 3789 \mathrm{~d}(\mathrm{c})(1)$.

74. See United States Attorney's Manual, Title 8 Civil Rights, 8-2000 Enforcement of Civil Rights Civil Statutes, § 8-2.241.

75. 42 U.S.C. $\$ 3789 \mathrm{~d}(\mathrm{c})(\mathrm{E})$.

76. Id. §3789d(c)(4)(A); Nat'l Black Police Ass'n, Inc. v. Velde, 712 F.2d 569 (D.C. Cir. 1983).

77. Omnibus Crime Controls and Safe Streets Act of 1968, Pub. L. No. 90-351, 82 Stat. 197 (1968).

78. For a historical discussion of LEAA's enforcement efforts of the Act, see Velde, 712 F.2d at 577. See also Note, Enforcing a Congressional Mandate; LEAA and Civil Rights, 85 YALE L.J. 721, 723-78 (1976).

79. United States v. City ofLos Angles, 595 F.2d 1386 (1979) (holding that the LEAA was justified in discontinuing funds to the Los Angeles Police Department when the Department refused to abandon certain racially discriminatory practices). 


\section{Title VI of the Civil Rights Act}

Acts of racial profiling by state and local law enforcement agencies, which receive federal funds, may be adjudicated under Title VI of the Civil Rights Act of $1964 .{ }^{80}$ This statute was promulgated to prohibit organizations, who receive federal funds, from discriminating on the basis of race, color, or national origin. Racial profiling typically involves these three bases of discrimination, e.g. African-American men and Latino men. The Justice Department coordinates enforcement of Title VI among all federal agencies that provide financial assistance to state and local governments. ${ }^{81}$ Under Title VI, the primary remedy given when the recipient engages in discriminatory conduct is the termination of federal funds. ${ }^{82}$

The Justice Department has also issued implementing regulations that establish a private cause of action based on Title VI. ${ }^{83}$ Further, the United States Supreme Court in Alexander v. Choate ${ }^{84}$ and Guardians Ass'n v. Civil Service Commission of New York City ${ }^{85}$ recognized a cause of action under Title VI and upheld the regulations when federal recipients engaged in discrimination. Thus, a private citizen can sue state and local enforcement agencies to obtain either injunctive relief or monetary damages for intentional discrimination. ${ }^{86}$ The Supreme Court in Alexander v. Sandova ${ }^{87}$ prohibited

80. Title VI provides: "[n]o person in the United States shall, on the ground of race, color, or national origin, be excluded from participation in, be denied the benefits of, or be subjected to discrimination under any program or activity receiving Federal financial assistance." 42 U.S.C. $§ 2000 \mathrm{~d}$ (2000).

81. Exec. OrderNo. 12,250, 28 C.F.R. $\S \S 42.401,42.415$ (F) (Coordination of Enforcement of Nondiscrimination in Federally Assisted Program).

82. For a historical review of Title VI and its provisions on termination of funding to recipients of federal financial assistance who engage in racial discrimination, see Velde, 712 F.2d at 577 . See also Linda R. Singer et al., Comment, Title VI of the Civil Rights Act of 1964-Implementation and Impact, 36 GEO. Wash. L. Rev. 824, 827 (1968); Notre Dame Conference on Federal Civil Rights Legislation's and Administration: A Report, 41 Notre Dame Law. 906, 922-24 (1966).

83. The Department of Justice's implementing regulations provide that no funding recipient shall utilize criteria or methods of administration which have the effect of subjecting individuals to discrimination because of their race, color, or national origin, or have the effect of defeating or substantially impairing accomplishment of the objectives of the program with respect to individuals of a particular race, color, or national origin. 28 C.F.R. $\$ 42.104$ (b)(2). For a discussion of Title VI's regulations on disparate impact, see Bradford C. Mank, Are Title VI's Disparate Impact Regulations Valid?, 71 U. CIN. L. Rev. 517 (2003); Note, After Sandoval: Judicial Challenges and Administrative Possibilities in Title VI Enforcement, 116 HARV. L. Rev. 1774 (2003) [hereinafter Note, After Sundoval].

84. Alexander v. Choate, 469 U.S. 287 (1985).

85. Guardians Ass'n v. Civil Serv. Comm'n of New York, 463 U.S. 582, 607-08 (1988).

86. See White v. Williams, 179 F. Supp. 2d 405, $422-24$ (D.N.J. 2002) (the court recognized that 
a private right of action under the regulations where only disparate impact discrimination is alleged. ${ }^{88}$ The Court did not find that the regulations were void; therefore, federal agencies should be able to pursue both disparate impact $^{89}$ and intentional discrimination claims against state and local enforcement agencies who engage in racial profiling.

Even though the Supreme Court has recognized a cause of action under Title VI and the regulations, it is difficult for a plaintiff to prove intentional discrimination under the statute. Plaintiffs have had some success with their claims of intentional discrimination in the racial profiling context. ${ }^{90}$ For example, in Rodriguez v. California Highway Patrol, ${ }^{91}$ the plaintiffs were able to establish a prima facie case that policies of the California Highway Patrol and the Bureau of Narcotics Enforcement had intentionally violated Title $\mathrm{VI}^{92}$ and violated Title VI regulations. ${ }^{93}$ Similarly, in Wilson v. Department of

a private citizen can seek both injunctive relief and damages under Title VI for racial profiling by state law enforcement agencies. However, the court denied the plaintiff's request for injunctive relief under Title VI because his claims were "nearly identical to those embraced by the Consent Decree" between the Justice Department and the State of New Jersey).

87. Alexander v. Sandoval, 532 U.S. 275 (2001).

88. Bryant v. Indep. Sch. Dist. No. I-38, 334 F.3d 928, 932 (10th Cir. 2003).

89. See Mank, supra note 83; see also Note, After Sandoval, supra note 83.

90. See, e.g., Gazarov v. Diocese of Erie, 80 Fed. Appx. 202 (3d Cir. 2003); Clyburn v. Shields, 33 Fed. Appx. 552 (2d Cir. 2002); Jackson v. Waguespack, C.A. 01-2972 Section "T”(4), 2002 U.S. Dist. LEXIS 20864 (E.D. La. Oct. 28, 2002); Craft v. Bd. of Trs., 793 F.2d 140 (7th Cir. 1986).

91. Rodriguez v. Cal. Highway Patrol, 89 F. Supp. 2d 1131 (N.D. Cal. 2000). The case was recently settled and the California Highway Patrol (CHP) agreed to collect and maintain data on racial stops, and place some limitations on car searches. Maura Dolan \& John M. Glionna, CHP Settles Lawsuit Over Claims of Racial Profiling, L.A. Times, Feb. 28, 2003, at 1. CHP also agreed to pay $\$ 725,000$ in legal fees and $\$ 50,000$ in damages to each motorist named in the suit. $I d$.

92. "To state a claim for damages under 42 U.S.C. $\$ 2000 d$, a plaintiff must allege that (1) the entity involved is engaging in racial discrimination; and (2) the entity involved is receiving federal financial assistance. Although the plaintiff must prove intent at trial, it need not be pled in the complaint." Fobbs v. Holy Cross Health Sys. Corp., 29 F.3d 1439, 1447 (9th Cir. 1994). In Rodriguez, plaintiffs met the pleading standard set forth in Fobbs. Rodriguez, 89 F. Supp. $2 \mathrm{~d}$ at 1139. Plaintiffs alleged that Defendants engaged in racial discrimination by stopping, detaining, interrogating and searching motorists on the basis of race, and they describe the discriminatory methods and practices Defendants allegedly employ. Id. Plaintiffs also alleged that CHP and BNE are recipients of federal funding. Id. Nothing more is required to state a claim under Title VI, although Plaintiffs also allege that Defendants acted with discriminatory intent. Id.

93. To establish a prima facie case that Defendants violated Title VI regulations, Plaintiffs must demonstrate that Defendants have a program, policy or practice that has a "discriminatory impact." Larry P. v. Riles, 793 F.2d 969, 982 (9th Cir. 1984). Plaintiffs alleged that CHP's drug interdiction efforts have a discriminatory impact on motorists of color. Rodriguez, 89 F. Supp. 2d at 1139. Anticipating Defendants' position that their drug interdiction tactics are justified by law enforcement necessity, Plaintiffs further alleged that these tactics are largely unsuccessful and therefore unjustified. See id. 
Public Safety,${ }^{94}$ the court granted the plaintiff's motion to proceed with a Title VI claim because the plaintiff adequately alleged that the state trooper made a traffic stop because of his race. ${ }^{95}$

A review of traffic stop data which indicates that African-Americans are disproportionately stopped by governmental officials, may support a claim of intentional discrimination. ${ }^{96}$ The plaintiff may seek both damages and equitable relief for intentional discrimination. The Justice Department could seek remedies under both theories of discrimination; intentional and disparate impact.

\section{State And Local Initiatives}

A number of states and local communities have taken a proactive approach to addressing the issue of racial profiling by promulgating statutes, ordinances, and policies prohibiting such conduct by law enforcement officers. Although the federal government's effort to promulgate legislation to require the collection of traffic stop data has lingered on for more than five years, states and local authorities have aggressively proceeded to enact such laws. ${ }^{97}$

The focus of racial profiling legislation has been directed at state police, e.g. troopers. However, racial profiling of minorities is not limited to state police. Law enforcement officials in municipalities, towns, and villages also participate in racial profiling. Thus, state racial profiling legislation should be broad enough to cover municipal officers, as well as state police. ${ }^{98}$

94. Wilson v. Dep’t of Public Safety, 66 Fed. Appx. 791 (10th Cir. 2003).

95. Id. at 795 .

96. See White v. Williams, 179 F. Supp. $2 d 405$ (D.N.J. 2002).

97. For a summary of the number of law enforcement agencies and states which have collected traffic stop data and states which prohibit racial profiling as of December 2001, see U.S. Department of Justice, Traffic Stop Data Collection Policies for State Police, 2001, NCJ 191158 (Dec. 2001).

98. Connecticut is one of the few states that racial profiling legislation covers more than state troopers. The statute states in part that no member of the Division of State Police within the Department of Public Safety, a municipal police department or any other law enforcement agency shall engage in racial profiling. Conn. Gen. Stat. § 54-1m (2001). The state of Oklahoma has a similar statute prohibiting racial profiling by any municipal, county or state law enforcement agency. OKLA. STAT. tit. 22 , 334.3 (2002). 


\section{A. Local Ordinances}

A growing number of municipalities have passed local ordinances prohibiting racial profiling by law enforcement officials. For example, in 2001, Cincinnati passed one of the first and most aggressive local ordinances outlawing all forms of racial profiling. ${ }^{99}$ Cincinnati police are required to record the race, color, ethnicity, gender, and age of individual motorists stopped by the police. ${ }^{100}$ Failure to comply with the ordinance could result in the termination of employment. ${ }^{101}$

A few cities have either passed or considered local ordinances criminalizing racial profiling. ${ }^{102}$ Those cities conclude that individuals who engage in racial profiling are engaged in a crime against the public; thus such conduct is a criminal offense and should be punished. Similar initiatives have resulted in several states passing legislation which makes racial profiling a crime. ${ }^{103}$ For example, in New Jersey, a violation of the state's racial profiling law is a third-degree offense that could result in three to five years imprisonment. ${ }^{104}$ Criminalizing racial profiling is the next logical step that states and municipalities should take to end such conduct. If cities and states are serious about ending racial profiling, criminal sanctions may be needed to punish those who continue to intentionally engage in racial profiling. When an officer's intention is to violate the constitutional rights of citizens, criminal penalties are justified. In addition, law enforcement officers found guilty of engaging in racial profiling should permanently be removed from their positions, as individuals with criminal records normally are disqualified from

99. Cincinnati, Ohio, Municipal Code, art. IV, § 4-A (2004). See also Bill Sloat, Racial Profiling Banned by Law in Cincinnati, Clev. Plain Dealer, Mar. 30, 2001, at B4.

100. Cincinnati Code, art. IV, $\S 4$-A.

101. Id. at Sec. 4-A(a) states, in part, any member of the police force who engages in racial profiling shall be subject to disciplinary action, in accordance with applicable civil service law, up to and including dismissal.

102. See Columbus Ohio, Code $\S 2331.01$ (A)(13) (2004); Nichole Aksomit, Council Votes Not to Push to Make Profiling a Felony, OMaha World Herald, Dec. 12, 2001, at 8b. The ordinance would have made racial profiling a Class IV felony with a maximum penalty of five years and a $\$ 10,000$ fine. $I d$.

103. For example, under Oklahoma's statute, racial profiling is a misdemeanor. OKLA. Stat. tit. 22, $\S 34.3$ (2002).

104. N.J. Stat. Ann. § 2C:30-5 (West 2003). The law states "law enforcement officers are prohibited from using racial characteristics or color, either alone or in conjunction with other composite characteristics such as a generalized vehicle description or the age of the driver or passengers as the basis for initiating an investigative stop." Id. See also Delores D. Jones-Brown, Should Racial Profiling Be a Crime?, N.J. LAw., June 2000, at 51; Michael Booth, N.J. Makes Racial Profiling by Public Officials a Crime, Broward Daily Bus. Rev., Mar. 19, 2003, at A7. 
serving in law enforcement positions. A combination of being charged with a crime and being removed from employment would serve as a deterrent to unlawful and unethical behavior by those law enforcement officers who intentionally violate the law.

\section{B. State Legislation}

A majority of states have passed legislation either prohibiting racial profiling and/or requiring law enforcement agencies to collect racial data on traffic stops. ${ }^{105}$ Inconsistencies exist among the states regarding what data should be recorded at traffic stops; ${ }^{106}$ however, their goals of determining if racial profiling occurs and how to correct it are similar. For example, the Governor of Wisconsin issued an executive order prohibiting state law enforcement agencies from using any form of racial profiling to determine who will be stopped or searched. ${ }^{107}$ The executive order also "[r]equires all enforcement agencies in the State of Wisconsin to enact a policy prohibiting the practice of racial profiling." 108 Prior to issuing the executive order, the Governor of Wisconsin created the Governor's Task Force on Racial Profiling to study racial profiling during traffic stops in Wisconsin. The Task Force also recommended training, community input, and the collection of data on traffic stops in communities. ${ }^{109}$ The study makes a number of recommendations on how to prevent racial profiling when officers are conducting stops. ${ }^{110}$

105. A selected list of state racial profiling statutes includes: R.I. GEN. Laws § 31-21. 1-4(d) (2001); Conn. Gen. Stat. 54-1m (2001); N.C. Gen. Stat. § 114-10 (1999); Okla. Stat. tit. 22 §§ 34.3, 34.4, 34.5; Mo. Rev. Stat. $\S \S 590.650,590.653$ (2002); Wash. Rev. Code $§ 43.43 .480$ (2003); Tex. Crim. Proc. Code Ann. $\S 2.131$ (Vernon Supp. 2003). For a review of racial traffic data collection in California, New Jersey, and North Carolina see, RAMIREZ ET AL., supra note 11.

106. For a review of racial profiling legislation see, Institute on Race \& Poverty, Components of Racial Profiling Legislation, available at http://www.umn.edu/irp/publications/racialprofiling.html (last visited Mar. 10, 2004); see also Northeastern University, Racial Profiling: Data Collection, available at http://www.racialprofilinganalysis.neu.edu/index.php (last visited Mar. 10, 2004). For a state by state review of racial profiling legislation, see Northeastern University, Racial Profiling: The State of the Law, available at http://www.policefoundation.org/pdf/racialprofiling.pdf (last visited Mar. 10, 2004).

107. Other state governors have issued similar Executive Orders. See Governor Signs Resolution Against Racial Profiling, available athttp://www.state.wy.us/governor/press_release/2001/july2001/racial. html (last visited Mar. 10, 2004); Governor Paul Patton Orders Study to Determine if Racial Profiling Exists, available athttp://dpa.state.ky.us/library/advocate/may00/profile.html (last visited Mar. 10, 2004).

108. Mark Johnson, Governor Orders Racial Profiling Ban, MiLwaukeE J. Sentinal, Mar. 7, 2001, at $2 \mathrm{~B}$.

109. Id.

110. $I d$. 
The State of Missouri has an extensive racial profiling statute which requires the recording of racial data and the reason why the motorist was stopped. ${ }^{111}$ All law enforcement agencies are also required to provide the data to the State Attorney General's Office to ensure that law enforcement agencies across the state comply with the statute. ${ }^{112}$ Additionally, there is a provision which allows the Governor to withhold state funds from law enforcement agencies who fail to comply with the statute. ${ }^{113}$

Other states have enacted legislation similar to Missouri and Wisconsin. For example, in North Carolina, the Traffic Enforcement Statistics SC 76 was signed by the Governor on April 22, 1999. ${ }^{114}$ On August 10, 2000, Massachusetts enacted a law requiring the collection of data on stopped motorists. ${ }^{115}$ A bill was introduced in the Ohio legislature that would require law enforcement agencies to collect racial, ethnic, and gender data on all traffic stops. ${ }^{116}$ In Texas, the criminal code prohibits the use of evidence that may be admitted in a criminal trial if that evidence was obtained illegally, e.g. racial profiling. ${ }^{117}$

The highways in New Jersey have become synonymous with racial profiling. In 1994, seventeen defendants convinced a state judge that their arrest by the New Jersey State Police was racially motivated. ${ }^{118}$ In State $v$. Pedro Soto ${ }^{119}$ the court held:

111. Mo. Rev. Stat. § 590.650 (2002).

112. $I d$.

113. Mo. Rev. Stat. § 590.650(6); see also Annual Report on 2001 Missouri Traffic Stops, available at $\mathrm{http} / / \mathrm{www}$.ago.state.us/racialprofiling/2001/racialprofiling2001.htm (last visited Mar. 10, 2004).

114. N.C. Gen. Stat. 114-10 (2002). See also Michael Grossman, High Point Police Collect Data on Race; The Checklist Will Prevent "Racial Profiling" in Stops, Police Say. State Officers Will Collect Similar Data, Greensboro News \& Record, July 16, 1999, at B1; Mike Ramsey, Getting to Know You, Sunday Star-News, May 30, 1999, at 1B, 5B.

115. 2000 Mass. ALS 228 (2000). For a detailed review of the Massachusetts statute see Suzanne Leone, Massachusetts Addresses Racial Profiling Head On: The Advocacy of Chapter 228 of the Acts and Resolves of 2000, 28 N.E. J. ON CRIM. \& CIV. CON. 335 (2002).

116. $\S 122$ H.B. 108, 124th Gen. Assembly (Ohio 2001-02).

117. Tex. Crim. Proc. Code Ann. $§ 38.23$ (Vernon 1998 \& Supp. 2004) (limiting the use of evidence at trial); see also Pruneda v. State, 104 S.W.3d 302 (2003). Similarly, in Gonsalves, the Supreme Judicial Court of Massachusetts suppressed evidence obtained by police during a traffic stop and search because the police officer did not have a reasonable basis to justify a stop, search, and order of the passenger out of the car. Commonwealth v. Gonsalves, 711 N.E.2d 108 (Mass. 1999). The court expressed concern that such conduct was sufficiently intrusive to violate their constitution. Id.

118. State v. Soto, 734 A.2d 350 (N.J. Super. Ct. Law Div. 1996).

119. Id. at 360 . 
[W] here objective evidence establishes "that a police agency has embarked upon an officially sanctioned or de facto policy of targeting minorities for investigation and arrest" any evidence seized will be suppressed to deter future insolence in office by those charged with enforcement of the law and to maintain judicial integrity. ${ }^{120}$

Four years later in 1998, New Jersey was again faced with even more egregious allegations of racial profiling when three African-American men and one Hispanic man were fired upon eleven times after being stopped for an alleged traffic violation. ${ }^{121}$ The four men were traveling to North Carolina to try out for a basketball team. ${ }^{122}$ After an investigation of the shooting and other allegations of racial profiling, the Attorney General of New Jersey conducted an investigation which revealed that racial profiling was indeed being practiced by state law enforcement officials. ${ }^{123}$ The issue of racial profiling was ultimately resolved when the U.S. Justice Department entered into a consent decree with New Jersey. ${ }^{124}$ Even with a comprehensive agreement between the Justice Department and New Jersey, there is evidence that racial profiling continues to occur in the state. ${ }^{125}$

Other states, which are serious about eradicating the practice of racial profiling, must take a proactive approach to address the issue in their state. ${ }^{126}$ Moreover, states should avoid the protracted internal and external investigations, lawsuits, ${ }^{127}$ negative press, and citizen distrust of state public

120. Id. (citing State v. Kennedy, 588 A.2d 834 (N.J. Super. Ct. App. Div. 1991)).

121. See Doug Most, Shot Through the Heart; The Hoop Dreams of Four Young Men Were Shattered - and the Issue of Racial Profiling was Brought into Sharp Focus-When New Jersey Troopers Stopped Their Van and Opened Fire, Sports Illustrated, July 10, 2000; see also White v. Williams, 179 F. Supp. 2d 405, 412 (D.N.J. 2002); Martin Mbugua \& Owen Moritz, N.J. Pays \$12.9M Settlement for 4 in Racial Profiling Case, Daily News, Feb. 3, 2001, at 5.

122. Id.

123. Peter Verniero \& Paul Zoubek, State Police Review Team, Interim Report of the State Police Review Team Regarding Allegations of Racial Profiling (Apr. 20, 1999); see also White, 179 F. Supp. 2d at 410-16 (outlining the development of racial profiling in the State of New Jersey).

124. New Jersey, Consent Decree, supra note 66.

125. See U.S. Department of Justice, How to Correctly Collect and Analyze Racial Profiling Data: Your Reputation Depends on It (2002) (finding that over 400 law enforcement agencies are collecting traffic-stop data).

126. For example, the Attorney General of Arizona sponsored two Racial Profiling Conferences. Janet Napolitano, Office of the Arizona Attorney General, Report on Racial Profiling (2001). A report of the findings indicate that law enforcement agencies and community advocates will be impacted by the following factors when addressing the issue: (1) the creation and implementation of law enforcement policies and procedures; (2) training for law enforcement and private residents; (3) diversity in hiring and promotional decisions, with an effort to retain diverse staff; (4) technology; (5) data collections; and (6) civil rights. $I d$.

127. See White, 179 F. Supp. 2 d at 408 n. 1 (listing the vast amount of ongoing litigation in the State of New Jersey involving racial profiling). 
officials by aggressively studying racial profiling and implementing safeguards to prevent and correct such behavior. ${ }^{128}$

\section{Collection of Data}

A number of municipalities and states are collecting statistical data on motorists who are stopped, detained, and searched by law enforcement officers. ${ }^{129}$ Cities such as Columbus, ${ }^{130}$ Sacramento, ${ }^{131}$ and Los Angeles ${ }^{132}$ have begun to collect and analyze such data. Similarly, in Florida, the highway patrol volunteered to collect race and gender statistics on every motorist with whom troopers come in contact while performing their duties. ${ }^{133}$

In addition to collecting data on traffic stops by race, organizations should implement plans to determine whether the data is statistically valid, ${ }^{134}$ whether

128. See New Jersey Confronts Its Past, St. Louis Post-Dispatch, Dec. 2, 2000, at 34 (summarizing the New Jersey situation in this manner: "It took a high profile shooting and 91,000 pages of internal documents ... to prove that state police routinely stopped and searched motorists based solely on the color of their skin").

129. See The New Jersey Senate Judiciary Committee's Investigation of Racial Profiling and the New Jersey State Police: Overview and Recommendation, available at www.njleg.state. nj.us/RacialProfiling/Overview.pdf (last visited Mar. 10, 2004) (proposing a number of recommendations including the end of consent searches on highways where the speed limit is 65 miles per hour and making racial profiling a third degree crime).

130. A recent study conducted of traffic stops in Columbus, Ohio revealed that:

Over 64,000 self-initiated traffic stops were conducted by the officers of the Columbus Police Department from November 2001 through October 2002. Of these stops, $56 \%$ of the drivers were perceived to be white, $36 \%$ were perceived to be black .... In the City of Columbus, the racial make-up of the population is $63.6 \%$ white, $24.6 \%$ black .... The study cautioned that the mere fact that blacks were stopped at a rate higher than their representations of the population, does not automatically result in a finding of racial profiling.

See Ohio State University, Center for Biostatistics, Analysis of Traffic Stop Data, City of Columbus Department of Public Safety, Final Report (June 24, 2003).

131. A report of vehicle stops in Sacramento, California between 2001-2002 revealed, in part, that "[a]mong drivers in Sacramento, African-Americans are stopped more often (in proportion to their representation in the population of the City of Sacramento) than white drivers, with the greatest overrepresentations of African-Americans occurring among drivers stopped between 9 PM and 5 AM." Howard Greenwald, Police Vehicle Stops in Sacramento, California: Second of Three Reports, at 39 (Jan. 2003). "African-American and Hispanic drivers are subject to more intrusive stops than white drivers. Tables ... indicate that African-Americans and Hispanic drivers are asked to exit their cars, searched, and detained for 30 minutes or longer about twice as often as white drivers." Id. at 32.

132. As a result of a consent decree with the U.S. Department Justice, the City of Los Angeles agreed to collect, data on traffic stops. Los Angeles Agreement, supra note 70.

133. Jill Taylor, Highway Patrol Plans to Collect Data to Debunk Profiling, The Palm Beach Post, Oct. 3, 1999, at 14A.

134. Castaneda v. Partida, 430 U.S. 482 (1977) (recognizing the analytical analysis of standard deviation model in establishing the probability that discrimination exist). See also Hazelwood Sch. Dist. 
the data will be used to support disciplinary actions, and how the data will be evaluated. ${ }^{135}$ Failure to anticipate these issues prior to passing such legislation will leave the data open to criticism and attacks. ${ }^{136}$

In recording such data, it is also crucial to identify the law enforcement officer recording it and to give individuals who are stopped a copy of the form indicating why they were stopped. ${ }^{137}$ The requirement of identifying the officer making the stop and recording the data has caused tension between law enforcement agencies and the Fraternal Order of Police. ${ }^{138}$ Nevertheless, states and municipalities continue to collect traffic stop data which includes the name of the law enforcement officer making the stop. When implementing such procedures that require the collection of traffic stop data, law enforcement agencies should ensure that the new policies and procedures do not violate the collective bargaining agreement. ${ }^{139}$

Without identifying the individual recording the data, it would be difficult to determine whether the respective officer has disproportionately stopped any particular racial group. ${ }^{140}$ The mere fact that a particular officer has

v. United States, 433 U.S. 299 (1977).

135. Racial Profiling Data, supra note 125; Ronald L. Davis, National Organization of Black Law Enforcement Executive, Racial Profiling: "What Does the Data Mean?” A Practitioner's Guide to Understanding Data Collection \& Analysis (2001) (outlining procedures for collecting data for racial profiling). It may also be beneficial for a research University to analyze the data to lend credibility to the outcome and findings. See Ramirez et al., supra note 11 (includes recommendations on developing trafficstop data collection systems).

136. Lori Montgomery, Racial Profiling in Maryland Defies Definition—or Solution, WASH. Post, May 16, 2001 at A1; Brandon Garrett, Remedying Racial Profiling, 33 Colum. Hum. RTs. L. Rev. 41 (2001).

137. See Montgomery County, Ohio Officer Initiated Stops of Drivers/Pedestrians, MSCO Form No. 0016 which requires the officer to provide the race and gender of the motorist, the reason for the stop, type of search, information on the occupants, whether contraband was found, and signature of the officer and supervisor.

138. See, e.g., F.O.P. v. City of Columbus (2002) (Stein, Arb) (unpublished ruling on file with author). The arbitrator ruled in part that "until such time as data from the Traffic Data Collection Program are determined to be statistically valid and reliable in accordance with commonly accepted statistical standards, the reviews or analysis of such data shall not be used to investigate or discipline a member ...." Id. See also Mark Ferenchik, Traffic-Stop Data Can't Be Used Against Officers, Arbitrator Rules, Columbus Dispatch, Mar. 8, 2002, at 4C.

139. Clarement Police Officers Ass'n v. City of Clarement, 5 Cal. Rptr. 3d 326 (Cal. Ct. App. 2003) (holding that the City's new policy requiring police officers to record the race and ethnicity of person stopped violated the collective bargaining agreement because the City was required to meet and confer with the Union before implementing the policy).

140. See White v. Williams, 179 F. Supp. 2d 405, 414-15 (2002) (indicating that the Consent Decree between New Jersey and the U.S. Department of Justice which prohibits racial profiling requires the collection of data which includes the "name and identification number of Trooper(s) who initiated the stop" and the "name and identification of Trooper(s) who actively participated in the stop"). 
disproportionately stopped a racial or ethnic group should not result in automatic disciplinary action. Further, training and development may be the appropriate remedy. ${ }^{141}$

Individuals who are stopped should be requested to verify not only their name and address, but also their race and gender. Further, a copy of the form should be given to the motorist to ensure that the officer has properly identified the motorist's race and ethnicity. ${ }^{142}$ This would address the issue of whether the officer is recording the personal data correctly. ${ }^{143}$ Because there are concerns that African-American and Hispanic males are the targets of such stops, the data should reflect the race and gender of the individuals. Such a policy was implemented by the Village of Mount Prospect. ${ }^{144}$ After litigation and a settlement agreement between two police officers who were allegedly instructed to target Hispanic drivers for traffic stops, the Village of Mount Prospect proposed the following policies and procedures to address the issue of racial profiling:

the Village has promised to enact a formal policy banning racial profiling, has eliminated ticket quotas for its officers, and will require officers to note the race of all drivers they stop. Additionally, the Village will create a computer database to track the racial and ethnic information collected by officers making traffic stops and aggressively recruit minorities for its police force. Finally, the Village will create a human rights review board, made up of a village manager, a resident, and a clergy member, to monitor racial profiling complaints as well as the information generated by the other reform efforts. ${ }^{145}$

Many other cities have developed similar policies and procedures to eradicate racial profiling in the enforcement of traffic laws. ${ }^{146}$ It is imperative that city officials understand that the collection of traffic-stop data is not the only answer to ending racial profiling. If the data reveals that racial profiling is practiced by officers, the data should be used to develop policies, internal

141. For example, Missouri's Racial Profiling statute “[p]rovides for appropriate counseling and training of any peace officer found to have engaged in race-based traffic stops within ninety days of the review.” Mo. Rev. Stat. $\$ 590.650$ (2002). Mount Prospect, Illinois policy states “[i]n concert with appropriate disciplinary action, additional diversity and sensitivity training shall be designated for officers with sustained racial profiling or other sustained discrimination complaints filed against them." Profiling Policies, Mount Prospect, Ill. Police Code § 132.4(B) (2004).

142. See, e.g., Chavez v. Ill. State Police, 251 F.3d 612 (7th Cir. 2001) (the officer recorded the motorist he stopped and searched as white, even though it was clear that the motorist was Hispanic).

143. See Columbus Report, supra note 130. The study indicated that the race of the individual recorded on the forms could not be verified because "there is no way to check whether the officer filled out the form correctly." Id.

144. Martinez v. Vill. of Mount Prospect, 92 F. Supp. 2d 780, 784 (N.D. Ill. 2000).

145. $I d$.

146. See supra note 133. 
procedures, training programs, and community partnerships to remedy such practices.

Cities and states that have already collected data on traffic stops should closely review it to determine whether law enforcement officials are engaging in unlawful conduct. For example, the New York State Attorney General reviewed 175,000 "UF-250" forms that were completed by the New York Police Department (NYPD). ${ }^{147}$ The review covered a period from January 1998 through March 1999 and showed that African Americans and Hispanics were disproportionately "stopped and frisked by NYPD officers."148 The study also revealed that a sample of the forms did not state facts sufficient to meet the legal definition of reasonable suspicion. ${ }^{149}$ These numbers clearly showed disparity in the enforcement of "stop and frisk" laws by the NYPD. In response to the study, the Attorney General stated that the next step was to identify "possible reforms;" $" 150$ in other words, remedies to address the issue of racial profiling.

147. Eliot Spitzer, Office of the Attorney General (New York), The New York City Police Department's "Stop \& Frisk" Practices: A Report to the People of New York from the Office of the Attorney General, at 2 (Dec. 1, 1999). Thirty-three percent of all "stops" were of Hispanics. Id. at 99. By contrast, Whites are $43.4 \%$ of the city's population, but accounted for only $12.9 \%$ of all "stops." Id. at 94-95.

148. Spitzer, supra note 147 , at $93-95$.

149. Id. at $160-62$.

150. Id. at $x v i$. 
Other cities ${ }^{151}$ and states ${ }^{152}$ which have collected data on traffic stops report that African-Americans and other minorities are disproportionately stopped by law enforcement officials; however, the reports stop short of concluding that such disparities are the result of racial profiling. ${ }^{153}$ The data, though not conclusive, illustrates that law enforcement officials have engaged in racial profiling. ${ }^{154}$

151. See Sacramento study, supra note 131; Columbus Report, supra note 130. In San Diego, a review of 91,500 traffic stops revealed that $40 \%$ of the motorists stopped were Blacks and Latino, even though they make up only $30 \%$ of the population. Mark Arner \& Joe Hughes, Police Stop Blacks, Latinos More Often; Data from Racial Profiling Report Echo Fears of S.D. Minorities, The San Diego UNION-TRIB., Sept. 29, 2000, at A-1. In Denver, motorists who perceived to be white constituted the largest percentage of stops but motorists perceived to be Hispanic and Black were searched at a higher rate than whites. Deborah Thomas, 1st Annual Report, Denver Police Department, Contract Card Data Analysis, at 7 (Oct. 2002). In Fort Worth, Texas, their racial profiling report revealed that AfricanAmericans represent $18.5 \%$ of individuals with vehicles but represented $25.6 \%$ of individuals who received traffic citations and $38.8 \%$ of motorists who were searched after being stopped. Fort Worth Police Department, Racial Profiling Report, January—December 2002 (Mar. 1, 2003).

152. In Missouri, the 2000 annual traffic report concluded that a review of 634 law enforcement agency stops of 453,189 motorists indicated that "African-Americans were stopped at a rate $27 \%$ higher than expected based solely on their proportion of the population, and when compared with whites." Missouri Attorney General's Office, 2000 Racial Profiling Report Overview from the Missouri Attorney General's Office, availableat http://www.ago.state.mo.us/racialprofiling/2000/racialprofiling2000.htm (last visited Mar. 10,2004). In Minnesota, traffic stop data collected by sixty-five law enforcement jurisdiction reported, in part:

Law enforcement officers stopped Black, Latino, and American Indian drivers at greater rates than White drivers, searched Blacks, Latinos, and American Indians at greater rates than White drivers, and found contraband as a result of searches of Blacks, Latinos, and Americ an Indians at lower rates than in searches of White drivers. Conversely, law enforcement officers stopped and searched White drivers at lower rates than drivers of color and found contraband in searches of White drivers at a greater rate than in searches of drivers of color.

Institute on Race and Policy, Minnesota Statewide Racial Profiling Report: All Participating Jurisdictions, Report to the Minnesota Legislative (Sept. 22, 2003).

A review of traffic stop data in Rhode Island from January 15, 2001, revealed in part:

In most communities in Rhode Island non-white drivers are stopped disproportionately to their presence in the driving population. Although no bright line was drawn to indicate a specific level of disparity that constitutes racial profiling, twenty jurisdictions were above statewide average levels of disparity.... Once stopped, non-white drivers in over half of the communities in Rhode Island are significantly more likely than whites to be subjected to a discretionary search.

Amy Farrell et al., Institute on Race and Justice, Rhode Island Traffic Stop Statistics Act, Final Report (June 30, 2003).

153. But see a study conducted for Counsel for Defendants stopped and arrested by Arizona Department of Public Safety Officers. The study concluded that the traffic data "strongly supports the claim that the Department of Public Safety Officers are engaging in a regular practice of disproportionately targeting African-Americans and Hispanic motorists on I-40 in Coconino County for stops. Frederic I. Solop, Statistical Analysis of I-40 Stop Data and I-40 Violator Study Data from Coconino County, Arizona, at 15-16 (Aug. 19, 2002).

154. For a summary of findings of traffic stop searches, see Racial Profiling Data, supra note 125, 
Understandably, for liability reasons, cities and states will not acknowledge that the data proves that law enforcement officials are engaged in racial profiling. However, where the evidence clearly supports that minorities are disproportionately stopped and searched, the cities and states should develop a plan to address why the disparity has occurred and how it should be addressed. ${ }^{155}$

\section{Training and Development}

In addition to collecting statistical data on motorist stops and passing ordinances and legislation that prohibit racial profiling, such laws should also include a provision mandating racial profiling training for law enforcement officers involved in the enforcement of traffic laws. ${ }^{156}$ Law enforcement officers should also receive sensitivity training on how their stereotypical biases regarding minorities, particularly African-Americans, may cause them to engage in racial profiling. Some local enforcement agencies have taken the initiative to develop training programs to prevent officers from engaging in racial profiling. ${ }^{157}$ Simultaneously, greater emphasis must be placed on recruiting and training new law enforcement officers. ${ }^{158}$ Officers must be

at $117-23$.

155. For example, in Rhode Island's traffic data collection report, disparity existed among white and non-white motorists when stopped. Farrell et al., supra note 152. Recommendations were included in the report to address the disparities. Id. For example, it was recommended in part that "[i]n departments that were identified as having racial disparities in either stop or search practices, supervision and monitoring programs should be established to help determine whether such disparities are the result of wide spread institutional practices or the actions of a smaller number of individual officers." Id.

156. For example, in Missouri, "Peace Officers who make traffic stops shall be required to receive annual training concerning the prohibition against racial profiling...." Mo. REV. STAT. $\$ 590.050$ (2002). For an outline of the training requirement in Missouri, see Chris Egbert, Racial Profiling Training Requirements for Peace Officers, available at http://www.dps.state.mo.us/dps/DPS2002/post/ RacialProfilingTrainingRequirements.htm (last visited Mar. 10, 2004).

157. Doug Caruso, Police to Address Racial Profiling, Colum bus Dispatch, May 23, 2001, at 1-E. The Cincinnati City Council proposed contracting with an independent constituent to conduct a "cultural audit" to determine the extent of racial biases within the police department. See Neil Seeman, Cincinnati, By the Numbers, NAT'L Rev., Apr. 20, 2001. The Florida Police Chiefs Association recommended that law enforcement agencies in Florida provide "In service" training to all officers of how to conduct stops without engaging in racial profiling. Florida Police Chiefs Association, Racial Profiling, available at http://fpca.com/profiling.htm (last visited Mar. 10, 2004).

158. In Virginia, new police officers throughout the state will be required to complete antidiscrimination training. Maria Glod, Va. to Train Police Against Profiling; New Policy Responds to Bias Complaints, WASH. Post, Aug. 21, 2003, at B7. Specific training standards to prohibit racial profiling was developed by the State. Id. 
trained on how to enforce laws in a respectful non-discriminatory manner. ${ }^{159}$ Officer recruitment may require new testing devices to eliminate applicants who are predisposed to developing racist tendencies. ${ }^{160}$ State and local governments should seek federal funds to assist with new training programs and initiatives. ${ }^{161}$

\section{Individual Citizen Response ${ }^{162}$}

\section{A. Citizen Complaints}

African-Americans, as well as other disenfranchised groups, should file complaints against individual police officers and governmental entities when they believe they were stopped without probable cause and suspect that their race was the motivating factor for the stop. ${ }^{163}$ Individual citizens must take on the role of a Rosa Parks when traveling the highway, the airport, or when shopping at the local mall. This entails filing a complaint with the local police department, contacting the newspaper, notifying the local civil rights

159. See John D. Cohen et al., End Racial Profiling, available at http://www.ndol.org/ blueprint/fall2000/cohen-lennon-wasserman.html (last visited Mar. 10,2004) (proposing four strategies on eliminating racial profiling, e.g. enhance technology to identify location of criminal activity, focus on "hot spots"- high crime areas, focus on high-risk offenders, and improve police recruitment and training).

160. The Minnesota racial profiling statute requires individuals interested in taking the peace officer licensing examination to take a psychological evaluation to determine if the applicant was likely to engage in racial profiling. MinN. STAT. § 626.8471(5)(b)(2) (2002).

161. Grants Aid Police in Fighting Racial Profiling, Boston Globe, Oct. 2, 2003, at 3 . The Justice Department's Office of Community Oriented Policing Services awarded $\$ 500,000$ to the Lowell Police Department "to help teach its officers about the dangers of racial profiling." Id.

162. Kathleen M. O’Day,Pretextual Traffic Stops: Protecting Our Streets or Racist Police Tactics?, 23 U. Dayton L. Rev. 313 (1998).

163. As a personal footnote, while returning my daughter to college on a two lane county highway in Southeast, Ohio I was stopped by the local police. Having driven that highway on many occasions, I was extremely careful to follow the speed limits when we approached a local community where the speed limit drastically went from $55 \mathrm{mph}$ to $35 \mathrm{mph}$. When stopped, I asked the officer why I was stopped and he indicated that I had been traveling $47 \mathrm{mph}$ in a $35 \mathrm{mph}$ zone. I disputed his conclusion. The officer requested my driver's license and insurance card, and then went back to his patrol car, possibly to check for any outstanding warrants. Having found none, he said he was letting me go with a verbal warning. I immediately went to the police station to file a complaint. The Chief of Police indicated they did not have a complaint form and couldn't understand why I was upset since I did not get a ticket. I explained that my stop was not incident to my being involved in violating any laws. The mere fact that I was stopped, my driving record checked for outstanding warrants, without probable cause, was a violation of my constitutional rights. The sheriff made up a form and I filed a complaint. 
organization, and the U.S. Justice Department. ${ }^{164}$ Minorities cannot solely rely on the courts and Congress to address this highly political issue.

\section{B. Civil Suits Under $\S 1983$}

African-Americans who are victims of racial profiling can pursue legal action under 42 U.S.C. $\S 1983^{165}$ on the basis that the state law enforcement officer's conduct violated the Fourth Amendment and the Equal Protection Clause ("Fourteenth Amendment") of the United States Constitution. ${ }^{166}$ The analysis for a Fourth and Fourteenth Amendment violation under $\S 1983$ are quite different. ${ }^{167}$ Under the Fourth Amendment, a traffic stop must only be reasonable. For example, did the officer observe a traffic violation or was there reasonable suspicion of a violation ${ }^{168}$ However, reaching a reasonable suspicion should be based on "individualized suspicion" and not on stereotypical biases or profiles directed at African-American citizens. ${ }^{169}$ Because this standard is a fairly easy standard to meet, law enforcement officers may engage in racial profiling without violating the Fourth Amendment. ${ }^{170}$

164. In an effort to address the issue of racial profiling, the Greater Washington Urban League published a pamphlet entitled "What to Do When Stopped by the Police" that outlines how motorists should act during a traffic stop. Richard C. Wolde, Brochure Offers Advice on Dealing with Police; Overall Theme: Try to Avoid Confrontations with Officers, WASH. Post, Nov. 10, 1994, at 1. Motorists are advised to file a written complaint with the local police department if they feel they were verbally or physically abused. $I d$.

165. 42 U.S.C. $\S 1983$ states in part:

Every person who, under color of any statute ... subjects or causes to be subjected, any citizen of the United States or other person within the jurisdiction thereof to the deprivation of any rights, privileges, or immunities secured by the Constitution and laws, shall be liable to the party injured in an action at law, suit in equity, or other proper proceeding for redress ....

42 U.S.C. $\$ 1983(2000)$

166. To survive a motion to dismiss, the U.S. Supreme Court stated the plaintiff must plead that 1) a person deprived him of a federal right and 2) the person who deprived him of that right acted under the color of state or territorial law. Gomez v. Toledo, 446 U.S. 635, 640 (1980). Recently, in White, the plaintiffs were able to survive a motion to dismiss their complaint of racial profiling by alleging sufficient facts, if proved at trial, that would be a violation of $\S 1983$. White v. Williams, 179 F. Supp. 2d 405 (D.N.J. 2002).

167. See Wilson v. Dep't of Pub. Safety, 66 Fed. Appx. 791 (10th Cir. 2003) (outlining two approaches to analyze a Fourth and Fourteen Amendment claim).

168. United Statesv. Bustillos-Munoz, 235 F.3d 505 (10th Cir. 2000); United States v. Ramstad, 308 F.3d 1139 (10th Cir. 2002).

169. United States v. Montero-Camargo, 208 F.3d 1122, 1135 (9th Cir. 2000); United States v. Rodriguez-Sanchez, 23 F.3d 1488, 1492 (9th Cir. 1994).

170. See Anthony C. Thompson, Stopping the Usual Suspects: Race and the Fourth Amendment, 74 N.Y.U. L. REV. 956 (1999). 
The U.S. Supreme Court has held that the practice of racial profiling violates the Equal Protection Clause of the Constitution. ${ }^{171}$ For a Fourteenth Amendment claim, the plaintiff must present evidence that the law enforcement official was motivated by race. ${ }^{172}$ To prevail under $\S 1983$, the plaintiff must prove that their constitutional rights have been violated. Without a violation of a constitutional right, there can be no violation of $\S 1983 .{ }^{173}$ In proceeding under $\S 1983$, the plaintiff has to prove that the articulated reasons for the stop were pretextual and that the stop was motivated by race. ${ }^{174}$ To prove pretext, the plaintiff has the difficult burden of proving that the law enforcement officer would not have stopped the plaintiff but for their race. ${ }^{175}$

The difficulty of prevailing in a $\S 1983$ case where racial profiling is alleged is illustrated in Flowers v. Fiore. ${ }^{176}$ In Flowers, an African-American motorist was mistakenly stopped, handcuffed, and his car was searched while police officers pointed their guns at him. ${ }^{177}$ A resident had called the police after he received threatening telephone calls that someone was sending two African-American men over with a gun. ${ }^{178}$ Flowers was merely driving his car in the neighborhood. ${ }^{179}$ In dismissing all the claims against the city and the officers, the court held that "[ $\mathrm{t}]$ hey had good reason to believe that Flowers

171. Whren v. United States, 517 U.S. 806, 813 (1996).

172. See Commonwealth v. Andres Lora, 16 Mass. L. Rep. 715 (Sup. Ct. Mass. 2003) (providing a summary of the Equal Protection analysis).

173. See City of Los Angeles v. Heller, 475 U.S. 796 (1986).

174. Washington v. Vogel, 880 F. Supp. 1542, 1544 (1995).

175. In Washington $v$. Vogel, the court held that "[t]he mere denial by the driver or occupants of a vehicle that the driver committed a traffic violation is insufficient, without more, for a reasonable jury to find that traffic stop was pretexual, and therefore race- or national origin-based." Id. at 1543. A newspaper investigation of search and cash seizures by a county sheriff's drug team on I-95 revealed that more than $\$ 8$ million dollars were seized primarily from African-Americans and Hispanic motorists. Steve Berry \& Jeff Brazil, Blacks, Hispanics, Big Losers in Cash Seizures: A Review of Volusia Sheriff's Records Shows that Minorities are the Targets in 90 Percent of Cash Seizures Without Arrests, The OrLAndo Sentinel, June 15, 1992, at A1. Eighty-five percent of individuals stopped, but not arrested, by the drug teams were African-Americans. $I d$. The primary reason for the stop was failure to maintain a single lane. $I d$. Even with this data the Court of Appeals upheld the order, stating "[ $[$ their evidence of a race-based policy, while highly disturbing, fails to demonstrate that the policy, and not traffic violations, prompted the individual officers in this case to conduct traffic stops." Ludmilla Lelis, Court Sides with Vogel in I-95 Case: An Appeals Court Upheld a 1995 Decision that Dismissed a Lawsuit over Cash Seizures, The ORLANdo Sentinel, Jan. 10, 1997, at D1.

176. Flowers v. Fiore, 239 F. Supp. 2 d 173 (D.R.I. 2003).

177. Id. at 176 .

178. $I d$.

179. $I d$. 
was armed and dangerous ...."180 The court further indicated that it was an unfortunate incident and that "[u]nder such circumstances, any citizen would be understandably upset and entitled to both a good explanation and an apology."181

As the court stated in United States v. Saucedo, ${ }^{182}$ the alleged victim has the burden of presenting "direct, circumstantial, or statistical evidence that he [or she] was a target of racial profiling." ${ }^{183}$ In determining whether there is an Equal Protection violation, the officer's subjective motivations may be explored. ${ }^{184}$ Further, in Von Herbert v. City of St. Clair Shores,${ }^{185}$ the court stated that "[m]ere speculation that police operatives had selected a suspect because of racial bias is inadequate to support a racial profiling charge."186

Individuals may also pursue other civil rights actions similar to $\S 1983$; however, courts are often unwilling to permit additional claims if a $\S 1983$ claim has been brought. For example, in White v. Williams, ${ }^{187}$ the plaintiff alleged that the defendants had not only violated $\S 1983$, but also $\S 1981,{ }^{188}$

180. Id. at 174 .

181. Id. at 179.

182. United States v. Saucedo, 226 F.3d 782 (6th Cir. 2000).

183. Id. at 790 .

184. See Farm Labor Org. Comm. v. Ohio State Highway Patrol, 308 F.3d 523, 533 (6th Cir. 2002).

185. Von Herbert v. St. Clair Shores, 61 Fed. Appx. 133 (6th Cir. 2003).

186. Id. at 149 .

187. White v. Williams, 179 F. Supp. 2d 405 (D.N.J. 2002).

188. 42 U.S.C. $\S 1981$ (a) provides:

All persons within the jurisdiction of the United States shall have the same right in every State and Territory to make and enforce contracts, to sue, be parties, give evidence, and to the full and equal benefit of all laws and proceedings for the security of persons and property as is enjoyed by white citizens, and shall be subject to like punishment, pains, penalties, taxes, licenses, and exactions of every kind, and to no other.

42 U.S.C. $§ 1981$ (a) (2000). 
$\S 1985,{ }^{189}$ and $\S 1986 .{ }^{190}$ In dismissing the $\S 1981$ complaint, the court in White stated that, "[a]lthough Section 1981 is a federal civil rights statute it is more appropriately analyzed in terms of a tort remedy." 191

\section{Class Action}

The procedural device of class action can be an effective tool to address the issue of racial profiling. Under Federal Rule of Civil Procedure $23,{ }^{192} \mathrm{a}$ class action can be certified by a federal court to enable a class of motorists to sue a municipality that engages in or permits racial profiling by law enforcement officers. For example, in Wilson v. Tinicum Township ${ }^{193}$ the court certified two classes and two sub-classes:

189. 42 U.S.C. $§ 1985(3)$ provides in pertinent part:

If two or more persons in any State or Territory conspire or go in disguise on the highway or on the premises of another, for the purpose of depriving, either directly or indirectly, any person or class of persons of the equal protection of the laws, or of equal privileges and immunities under the laws; or for the purpose of preventing or hindering the constituted authorities of any State or Territory from giving or securing to all persons within such State or Territory the equal protection of the laws ..., or cause to be done, any act in furtherance of the object of such conspiracy, whereby another is injured in his person or property, or deprived of having and exercising any right or privilege of a citizen of the United States, the party so injured or deprived may have an action for the recovery of damages occasioned by such injury or deprivation, against any one or more of the conspirators.

42 U.S.C. $\$ 1985$ (3) (2000). This adds little to $§ 1983$ in the context of constitutional violations like equal protection. See Mark R. Brown \& Kit Kinports, Constitutional Litigation Under Section 1983, at $12-13$ (2003).

190. 42 U.S.C. $\S 1986$ provides in pertinent part:

Every person who, having knowledge that any of the wrongs conspired to be done, and mentioned in section 1985 of this title, are about to be committed, and having power to prevent or aid in preventing the commission of the same, neglects or refuses so to do, if such wrongful act be committed, shall be liable to the party injured, or his legal representatives, for all damages caused by such wrongful act, which such person by reasonable diligence could have been prevented; and such damages may be recovered in an action on the case; and any number of persons guilty of such wrongful neglect or refusal may be joined as defendants in the action .... .

42 U.S.C. $§ 1986$ (2000). This is seldom used, and less effective. See Linda E. Fisher, Anatomy of an Affirmative Duty to Protect: 42 U.S.C. Section 1986, 56 WASH. LeE L. Rev. 461 (1999).

191. White, 179 F. Supp. 2d at 419. See also St. Francis Coll. v. Al-Khazraj, 481 U.S. 604 (1987) (holding § 1981 prohibits racial discrimination in the making and enforcement of contracts).

192. FED. R. Civ. P. 23(a) outlines the following prerequisites for a class action "(1) the class is so numerous that joinder of all members is impracticable [numerosity]; (2) there are questions of law or fact common to the class [commonality]; (3) the claims or defenses of the representative parties are typical of the claims or defenses of the class [typicality]; and (4) the representative parties will fairly and adequately protect the interests of the class [adequacy of representation]." See also Gen. Tel. Co. of the Southwest v. Falcon, 457 U.S. 147 (1982).

193. Wilson v. Tinicum Township, No. CIV.A.92-6617, 1993 WL 280205 (E.D. Pa. July 20, 1993). 
Class I: Injunctive classes certified pursuant to Fed. R. Civ. P. 23(b)(2) consisting of (a) all individuals who travel or will travel I-95 through Tinicum Township and (b) all African American and Hispanic individuals who travel or will travel I-95 through Tinicum Township. Class II: Damage classes certified pursuantFed. R. Civ. P. 23(b)(3) consisting of (a) all individuals traveling I-95 who have been stopped or subjected to searches and seizures by the defendants since November 18, 1990 as a result of defendants alleged customs and policies of stopping travelers on I-95 for pretextual traffic violations with the intent of coercing consent or improperly searching the stopped vehicles for drugs and (b) all African American and Hispanic individuals traveling on I-95 since November 18, 1990 who have been stopped or subjected to searches or seizures as a result of defendants' alleged policy or custom of stopping and searching minority individuals on I-95 because of their minority status. ${ }^{194}$

In Wilson, four African-Americans returning from a church celebration were stopped along I-95 by officers of Tinicum Township. ${ }^{195}$ The individuals were lined up on the shoulder of the road and searched by a police dog. ${ }^{196}$ The police officer admitted that the motorists were stopped because they were "young, black, and in a high drug-traffic area, driving a nice car." 197 Plaintiffs provided sufficient evidence to justify the certification of a class action involving African-American and Hispanic individuals who had been stopped and subjected to searches as a result of policy. ${ }^{198}$ The following year, the case was settled for monetary damages. ${ }^{199}$ A consent decree was also signed which included language that the police would not "stop, detain, search or arrest any person" due to race, ethnic identity or without probable cause. ${ }^{200}$ More recently, in Daniels v. City of New York, ${ }^{201}$ plaintiffs sought class certification under Rule 23 when they alleged that a unit of the NYPD known as the Street Crime Unit (SCU) had repeatedly conducted stops and frisks of AfricanAmerican and Latino men between the ages of twenty-three and thirty-seven years old who resided in the Bronx, Brooklyn, Manhattan, and the City of Rochester. ${ }^{202}$ In certifying the class, the court stated in part:

194. Id. at $* 1-2$.

195. Id. at *2.

196. $I d$.

197. Id.

198. $I d$. at $* 5$.

199. Emily Culbertson, Township Pays \$200,000 over Traffic Stops: Agreement Settles Suit Filed by Minorities Driving on I-95, The Legal InTELligencer, Oct. 7, 1994, at 1.

200. $I d$.

201. Daniels v. City of New York, 198 F.R.D. 409, 422 (S.D.N.Y. 2001) (oral argument was heard and an Opinion and Order denying reconsideration was issued on March 15, 2001). See Daniels v. City of New York, 199 F.R.D. 513 (S.D.N.Y. 2001).

202. Daniels, 198 F.R.D. at 411-12. Plaintiffs cited a study by the Attorney General's office that SCU reported over 18,000 stops and frisks in 1997 with a $50 \%$ increase in 1998. Id. at 412 . The report further stated that $62.7 \%$ of these stops involved blacks and $27.5 \%$ involved Latinos. Id. 
The classes of persons which plaintiffs here propose are challenging the same alleged illegal conduct of the defendants namely, the unconstitutional policy of stopping, detaining, and searching cars and their occupants without cause or proper consent. In addition, the minority classes which plaintiffs propose allege that they have been targeted for special attention in implementing the alleged unconstitutional policy. The claims plaintiffs assert, therefore, involve a common central issue: whether the defendants engaged in violations of the proposed class member's rights under the Fourth and Fourteenth Amendments of the United State Constitution and the laws of the Commonwealth of Pennsylvania. ${ }^{203}$

Based on the court's analysis of Rule 23 in Wilson and Daniels, plaintiffs may successfully proceed with a class action suit against a municipality for racial profiling. Once a class action has been certified by the court, defendants are more likely to seek resolution of the dispute in lieu of a full trial. Class action settlements not only benefit the plaintiffs, but other minorities who may be impacted by discriminatory practices in the future. ${ }^{204}$

203. Id. at 419-20 (citing Wilson v. Tinicum Township, No. CIV.A.92-6617, 1993 WL 280205, at *5 (E.D. Pa. July 20, 1993)).

204. See, e.g., Ledford v. City of Highland Park, No. 00-C-4212, 2000 U.S. Dist. LEXIS 11101 (N.D. Ill. July 31, 2000). In Ledford, the court certified a class of persons likely to be subjected to racial profiling in the past and future. Id. Plaintiff alleged that the Highland Park Police Department "maintains policies, practices, and customs which have the result of or require [police department] officers to target persons for surveillance, stops [, and] detentions . . on the basis of race." Id. at *1. The parties negotiated the proposed settlement:

(1) Prohibit all HPPD officers from considering race or ethnicity, in any fashion or to any degree, in deciding whether to surveil, stop, detain, interrogate, request consent to search, or search any civilian; except when officers are seeking to detain, apprehend or otherwise be on the lookout for a specific suspect sought in connection with a specific crime who has been identified or described, in part, by race or ethnicity in determining whether reasonable suspicion exists that a given individual is the person being sought.

(2) Document every incident involving a stop, detention, interrogation, and/or search of a civilian, including the race of the civilian involved, and facilitate the analysis of this data by recording and storing it on a computerized data system.

(3) Install audio and video equipment in certain HPPD vehicles.

(4) Use the materials in paragraphs (2) and (3) above to supervise HPPD officers.

(5) Maintain a system of investigating and resolving civilian complaints regarding HPPD officers.

(6) Provide specific training for HPPD officers.

(7) Allow plaintiffs' counsel to inspect materials in paragraphs (2), (4), and (5) above.

The court will retain jurisdiction for three to five years to enforce the terms of the Consent Decree. Id. at *11-12. 


\section{Community and Organization Initiatives}

\section{A. Community Initiative Response $e^{205}$}

In addition to campaigning for state and local laws to collect data on traffic stops, community organizations and local enforcement agencies can begin to address the issue of racial profiling by working together to identify solutions. Community groups can lobby for state and federal laws prohibiting racial profiling of motorists. ${ }^{206}$ This may entail organizing an advisory council, a community relations commission, and other boards to specifically address how to end racial profiling. Enacting various state laws and local ordinances cannot eliminate many centuries of conflicts between law enforcement and the African-American community, particularly AfricanAmerican males and the police. In order to remedy such conflicts, there must be an on-going and meaningful dialogue on racial profiling between various racial and ethnic groups and the police. ${ }^{207}$

Where city officials and law enforcement agencies fail to adequately address racial issues facing the African-American community, organizations have engaged in boycotts against white businesses. ${ }^{208}$ This occurred in Cincinnati when the Black United Front (BUF) contacted groups who had planned to have their conventions in Cincinnati. ${ }^{209}$ BUF asked the groups to move their convention to another city because of the unresolved racial issues in the city, especially racial profiling. ${ }^{210}$ The use of boycotting white businesses is not a new approach to pressing political leaders to end patterns and practices of racial discrimination. However, leaders of such boycotts may face litigation if they pursue this method of attacking racial profiling. ${ }^{211}$

205. Kathy Barrett Carter \& Brian Donohue, Profiling Admission Opens Door to a Class-Action Suit, The Star-Ledger, Apr. 22, 1999.

206. For example, the Access Coalition based in New York is lobbying for federal legislation to ban racial profiling. See Scott Bowles, Bans on Racial Profiling Gain Steam Legislatures Across the USA Debate the Police Practice of Stopping Motorist Based on Their Race, USA TodAY, June 2, 2000, at 3A.

207. Holly J. Wolcott, Oxnard Responds to Complaints of Racial Profiling, L.A. Times, May 6, 2002 , at B4.

208. See WLWT Eyewitness News, Activists Demand Boycott of Cincinnati, available at http://www.channelcincinnati.com/news/873627/detail.html (last visited Mar. 10, 2004).

209. $I d$.

210. $I d$.

211. WLWT Eyewitness News, Boycott Battle Headed for Court, available at http://www.channelcincinnati.com/news/1302578/detail.html (last visited Mar. 10, 2004). 


\section{B. Civil Rights Organizations}

Civil rights organizations have historically fought in and out of court for the civil rights of minorities. In particular, the National Association for the Advancement of Colored People (NAACP) ${ }^{212}$ and the American Civil Liberties Union (ACLU) ${ }^{213}$ have led the fight to end racial profiling. Courts have held that such organizations have standing to bring litigation to protect minorities from racial profiling by law enforcement agencies. ${ }^{214}$ The NAACP has been successful in pursuing class action suits against municipalities who engage in racially discriminatory stops, ${ }^{215}$ as well as implementing negotiation agreements to prohibit racial profiling. ${ }^{216}$

The ACLU has taken a national and aggressive position in combating racial profiling. ${ }^{217}$ The ACLU has pursued a number of cases in federal court against municipalities, which have resulted in large monetary awards and settlements. ${ }^{218}$ The ACLU Chapter in California has also established a telephone hot-line to gather data from individuals who are routinely stopped by law enforcement officers.

212. Hillary Shelton, Congressional Testimony, May 12, 1999, 1999 WL 16947587. See, e.g., Hugh R. Morley, Black Leaders, Police Join Hands: Panel to Deal with Race Issues, Bergen Record, Oct. 14, 1999, at L1 (Bergen County, New Jersey established a nine-member law enforcement and community outreach for the African American Advisory Committee).

213. In 1999, the ACLU issued an extensive report "Driving While Black" which provides statistics on traffic stops, the history of racial profiling, and the link between racial profiling and the war on drugs. David Harris, Driving While Black, available at $\mathrm{http} / / / \mathrm{www} . \mathrm{aclu} . \mathrm{org} / \mathrm{profiling} / \mathrm{report} / \mathrm{index} . \mathrm{html}$ (last visited Mar. 10, 2004); see also ACLU, Police Practices, available at http://www.aclu.org/issues/ policepractices/hmpolice.html (last visited Mar. 10, 2004).

214. See Rodriquez v. Cal. Highway Patrol, 89 F. Supp. 2d 1131 (N.D. Cal. 2000) (upholding the right of the NACCP and the California League of United Latin American Citizens (LULAC) to bring suit alleging that agencies of the state "maintain[ed] a policy, pattern and practice of targeting AfricanAmericans and Latinos in conducting stops, detentions, interrogations and searches of motorists").

215. Md. State Conference of NAACP Branches v. Md. Dep’t of State Police, 72 F. Supp. 2d 560 (D. Md. 1999).

216. See, e.g., Agreement Between St. Paul Police Department and St. Paul Chapter of the NAACP, available at http://www.ci.stpaul.mn.us/depts/police/agreement.pdf(last visited Mar. 10, 2004) (the parties agreed, in part to "continue dialogue with community organizations and citizens to improve policies and practices dealing with racial profiling including: expanded data collection and measurement, complaints and investigation, recruitment and training, and stops, searches and seizures, to which further amendments to this agreement may be forthcoming.").

217. See, e.g., Leland Ware, New Approaches to Ensuring the Legitimacy of Police Conduct, 22 St. Louis U. Pub. L. Rev. 59 (2003).

218. Robert Jackson, Eagle County Must Pay for Stopping Motorist: ACLU Wins $\$ 800,000$ Settlement for Drivers Stopped Because They Fit Drug Courier Profile, Rocky Mount An News, Nov. 10 , 1995, at 4A. 
Along with the ACLU and the NAACP, a number of other civil rights organizations in California formed the Racial Justice Coalition to promote the passage of a bill requiring law enforcement agencies to collect data on the race and ethnicity of motorists stopped by officers. ${ }^{219}$ Civil rights organizations around the country should join forces to promote laws to collect similar data in their respective cities and states. Once data is collected and it appears that law enforcement officials have engaged in racial profiling, civil rights organizations should begin to campaign for city and state officials to take corrective action. ${ }^{220}$

Additionally, civil rights organizations may need to provide financial assistance for individuals to bring civil suits against local enforcement agencies. ${ }^{221}$ Without financial support, African-Americans may not be able to vindicate violations of their civil rights. ${ }^{222}$

The National Organization of Black Law Enforcement Executives (NOBLE) has been instrumental in providing training for law enforcement agencies on recognizing and preventing racial profiling. ${ }^{223}$ In addition,

219. According to a March 13,2000 news release by the American Civil Liberties Union of Northern California, the following organizations formed the Racial Justice Coalition:

The coalition consists of a broad array of organizations, such as the American Civil Liberties Union (ACLU), California State Conference of NAACP Branches (California NAACP), California League of United Latin American Citizens (California LULAC), the California Urban League, Ella Baker Center for Human Rights, Asian Law Caucus, La Raza Centro Legal, Lawyers' Committee for Civil

Rights of Bay Area (LCCR), United Farm Workers (UFW), and numerous local organizations. ACLU-NC, News Release, available at http://www.sanmateocountylulac.org/racprofil.html (last visited Mar. 10, 2004).

220. See, e.g., ACLU-NC, NAACP, ACLU-NC, MALDEF and Other Civil Rights Groups Call for Major Police Reforms in Sacramento, available at http://www.aclunc.org/pressrel/030214-sactopolice.html (last visited Mar. 10, 2004) (after release of the second Sacramento Police Department's report on vehicle stops which showed that African-Americans and Latino motorists were disproportionately stopped by police, the civil rights organizations sought some form of corrective action).

221. See Purvette A. Bryant, Vogel Settles I-95 Lawsuit for \$25,000; The President of the NAACP Called the Settlement not only a Victory for the Two Plaintiffs but for all Minorities, THE ORLANDo Sentinel, Jan. 13, 1998, at A1 (two minority motorists sued the county sheriff department for violating their civil rights when they were stopped on I-95 based on their race and ethnicity).

222. In Price v. Krame, the Second Circuit affirmed a jury verdict of $\$ 245,000$ in favor of two African-American teens who the court described as teens "happily and quietly celebrating their graduation from prep school." Price v. Krame, 200 F.3d 1237, 1240, 1256 (2d Cir. 2000). The court further points out that police harassment of African Americans and Hispanic males is a reoccurring event across the country, however, in this case, "the youngsters had the wherewithal and families with the legal knowledge and economic resources to seek justice for the wrongs committed." Id. at 1256. Too often African Americans and Hispanics do not know or understand their rights under the Fourth Amendment; even if they are aware of their rights, they lack the necessary financial resources to vindicate their rights.

223. See NOBLE, Training, available atwww.noblenatl.org/training.htm (last visited Mar. 10, 2004). For example, in 2001, NOBLE held a conference in Richmond, Virginia entitled Integrity in Policing: 
NOBLE has conducted a national study on collecting and analyzing racial profiling data. ${ }^{224}$

\section{State and Local Bar Association Initiatives}

State and local bar associations, as well as other legal associations, can play a major role in addressing the issue of racial profiling in their locales. Indeed, state and local organizations can use its membership to leverage state legislatures into enacting statutes outlawing such conduct. For example in 1999, the Columbus Bar Association, in Ohio, appointed a Racial Profiling Task Force to examine the issue of racial profiling in central Ohio. The Task Force made the following recommendations to law enforcement agencies:

[1] Voluntarily institute a system of data collection and analysis of all traffic stops; [2] install video and audio equipment on all police cruisers; [3] establish sensitivity training for all police officers regarding racial profiling concerns; [4] simplify the process by which citizens may file complaints of racial profiling; and [5] strengthen community outreach to publicize the rejection of racial profiling tactics and avenues available for filing complaints. ${ }^{225}$

Other bar associations such as Delaware ${ }^{226}$ have implemented a variety of initiatives to combat racial profiling in their state. In addition, the American Bar Association has expressed support of federal legislation prohibiting racial profiling. ${ }^{227}$

\section{Local Enforcement Organizations}

In the midst of allegations of racism, lawsuits, and pending legislation, local police departments must develop and implement internal policies and programs to end the practice of racial profiling. Recently, the Police

Views on Racial Profiling. See also Mark Bowes, Pitfalls Seen to Traffic-Stops Surveys: VA. Chief: Test Must Be Comprehensive, Richmond Times Dispatch, June 28, 2001, at B-4.

224. NOBLE, Racial Profiling Resource Available, available at http://www.noblenatl.org/news/ publish/article_440.shtml (last visited Mar. 10, 2004).

225. Columbus Bar Association, Report of the Racial Profiling Task Force, at 38 (Jan. 2001).

226. The Delaware State Bar Association, Multicultural Judges and Lawyers Section developed the Project Integrity to address the issue of racial profiling. Delaware State Bar Association, Notes and Information, available at http://www.pacdelaware.com/dsba/MJL.html (last visited Mar. 10, 2004). The initiative involves the Bar Association working with the Delaware State Police Department and other state transportation agencies to develop programs to address racial profiling in the state. Id.

227. American Bar Association, Legal Remedies to Eliminate Discrimination, available at http:/www.abanet.org/poladv/priorities/discrim.html (last visited Mar. 10, 2004). 
Commissioner of New York City issued an order entitled "Department Policy Regarding Racial Profiling." 228 The policy defines racial profiling, prohibits such conduct, and mandates that officers have a legitimate reason for stopping and searching motorists. ${ }^{229}$ Similarly, the St. Louis Board of Police Commissioners adopted language in their police manual prohibiting the use of racial profiling in stopping motorists. ${ }^{230}$ Likewise, police departments across the country have committed to ending racial profiling by issuing directives, collecting data, ${ }^{231}$ and conducting studies on traffic stops and arrests.

Often, African-American motorists who are stopped by law enforcement officers are treated in a disrespectful manner and with a lack of cultural sensitivity, which results in the perception that they were stopped because of racial profiling. Law enforcement officers who have little or no contact with African-Americans and other minorities may fail to understand how to effectively communicate with individuals from different backgrounds and cultures. To address this issue, law enforcement agencies should include sensitivity and respectful conduct in their training program. For example, the Floridian Police Chief's Association issued a "Sample Professional Traffic Stops Policy and Procedure" which outlines, in part, procedures for greeting motorists in a professional manner and how to defuse tension during the stops. ${ }^{232}$ The sample also includes a complaint processing system for handling racial profiling complaints in a timely manner. ${ }^{233}$ Every law enforcement agency should have a complaint processing system which permits motorists

228. The order states in part that:

officers must be able to articulate the factors which led them to take enforcement action, in particular those leading to reasonable suspicion for a stop and questions, or probable cause for the arrest. Officers are also reminded that the use of characteristics such as religion, age, gender, gender identity, or sexual orientation as determinative factors for taking police action is prohibited.

New York City Police, Department Policy Regarding Racial Profiling, Order 11; see also Sean Gardiner \& Leonard Levitt, Race Profiling Ban; Kelly Puts Police Department Policy in Writing, Newsday, Mar. 4, 2002 , at A3.

229. Gardiner \& Levitt, supra note 228.

230. Ending Racial Profiling, St. Louis Post-Dispatch, Feb. 17, 2000, at B6.

231. James H. Burnett III, Police to Gather Racial Data on Drivers Involved in Traffic Stops; Effort Aimed at Finding out if Racial Profiling Exists, to Begin in 18 Months, Milwaukee J. Sentinel, Mar. 25, 2000, at 1A. In Arizona, law enforcement organizations, including the Sheriff's Association, Highway Patrol and the Fraternal Order of Police signed and issued a Declaration of Arizona Law Enforcement Condemning Racial Profiling, available at www.ag.state.az.us/law-enforcement/racial profiling.pdf (last visited Mar. 10, 2004).

232. Florida Police Chiefs Association, Racial Profiling, Sample Professional Traffic Stops Policy and Procedure, available at http://www.fpca.com/profilesamplepolicy.htm (last visited Mar. 10, 2004).

233. Id. 
to file a complaint when they believe they were stopped because of their race. The investigation and resolution of the complaint may avoid protracted litigation. Similar processes have been developed by other law enforcement organizations to prevent incidents of racial profiling. ${ }^{234}$

In a joint effort to end racial profiling in Ohio, ${ }^{235}$ top law enforcement agencies signed a pledge to prohibit any form of racial profiling by their respective organizations. ${ }^{236}$ Even though such pledges have no enforcement provisions, this constitutes a good faith effort to recognize the commitment to eliminating racial profiling. Clearly, future efforts and enforcement mechanics will be needed by each agency to fully eradicate the continued use of racial profiling.

\section{CONCLUSION}

Racial profiling by law enforcement officials in this country is an everyday occurrence. African-Americans are the primary victims of racial profiling, as some law enforcement officers perceive that all AfricanAmerican citizens are engaged in crime and lawlessness. Thus, such individuals are stopped, searched, and arrested without sufficient probable cause to justify law enforcement action. These stereotypical biases are racist assumptions which breed resentment and hostility between African-Americans and law enforcement officers. Without viable remedies to end racial profiling, race relations in this country, especially between African-Americans and law enforcement officers, will continue to deteriorate.

234. International Association of Chiefs of Police, Current Legal Issues in Racial Profiling, available at http://www.aele.org/losrace2000.html (last visited Mar. 10, 2004).

235. See, e.g., MacDaniel, Police Chiefs Vote to Curb Racial Profiling, Boston Globe, June 14, 2000, at B3. The executive board of the Massachusetts Police Chiefs Association voted to review and modify traffic stops to avoid racial profiling. $I d$.

236. Connie A. Higgins, Top Law Agencies Sign Racial-Profiling Pledge, Columbus Dispatch, Feb. 24, 2000, at 3D. The following organizations signed the pledge: "the State Highway Patrol, Ohio Association of Chief of Police, Buckeye State Sheriffs' Association, National Organization of Black Law Enforcement Executives, Fraternal Order of Police of Ohio, and The Ohio State Troopers Association." Id. 